\title{
El arte de los reinos taifas: tradición y ruptura
}

\author{
Susana CALVO \\ Universidad Complutense de Madrid
}

El periodo de los reinos de taifas (mulūk al-tawâ'if) suele definirse como un momento de debilidad e inestabilidad política y militar en al-Andalus, un territorio dividido en pequeños reinos que vivían amenazados por dos poderes en alza, los reinos cristianos del norte, sobre todo con Alfonso VI, y los beréberes del sur. No obstante, y en paradójica oposición, el siglo XI también se caracterizó por el esplendor cultural y artístico.

Las cortes taifas del siglo XI proporcionaron de sí mismas una imagen hedonista y "humanística", donde la literatura y el arte, además de las ciencias, servían para consolidar el poder de los soberanos y otorgarles la legitimidad que les negaban los campos de batalla. La ostentación del lujo y del saber, la emulación de modelos califales y sus referentes orientales o la competencia artística y cultural entre los diferentes reinos compensaban la falta de estabilidad política y territorial de unos poderes ${ }^{1}$ que pagaban parias a Alfonso VI a cambio de mantener la paz en las fronteras. Una serie de códigos cortesanos expresados a través de la literatura y de las diversas manifestaciones artísticas se pusieron al servicio de los nuevos reinos y contribuyeron no sólo a su consolidación sino también a su enriquecimiento y visibilidad. Para ejemplificar este esplendor hemos escogido algunas de las obras de arte más significativas del período, algunas muy estudiadas y otras de más reciente aparición y en las cuales estamos trabajando.

En el surgimiento y afianzamiento de estos reinos intervinieron múltiples factores, como han puesto de relieve los historiadores del periodo ${ }^{2}$. Algunos estudios recientes

El presente artículo ha sido realizado en el marco del Proyecto de Investigación del Plan Nacional I+D+I con ref. HAR2009-08901, dirigido por J. C. Ruiz SouzA, "La Génesis del Estado Moderno y el palacio especializado".

1 P. Guichard y B. Soravia, Los reinos de taifas: fragmentación politica y esplendor cultural, Málaga, 2006, p. 95. Consideran los autores que estos reinos eran estados imperfectos.

2 M. AciÉn Almansa, "Del estado califal a los estados taifas: la cultura material", Actas del V Congreso de Arqueología Medieval Española (Valladolid, 22 a 27 de marzo de 1999), Valladolid, 2001, pp. 493-513. La clasificación más habitual de las dinastías taifas se hace con arreglo a su origen racial: taifas beréberes, árabes o eslavas. M.J. VIGUeRA Molins, Los reinos de Taifas y las invasiones magrebies. Al-Andalus del siglo XI al XIII, Madrid, 1992, pp. 40-44; y P. GuIchard y B. SoraVIA, Los reinos de taifas..., op. cit., pp. 41-61. 
centrados en el análisis de las fuentes escritas, la epigrafía y la numismática han mostrado la existencia de unas dinastías taifas claramente "rupturistas" respecto a la tradición califal frente a otras dinastías de carácter "legitimista". Los Banu Hud de Zaragoza, por ejemplo, omitieron el nombre del califa en la leyenda de sus monedas, al igual que hicieron los dulnunnies toledanos y los aftasies de Badajoz, razón por la cual se las considera taifas "rupturistas" desde el principio. Los abbadies de Sevilla se unieron más tarde a esta corriente, en la segunda mitad del siglo, mientras que los tuyibíes (primero en Zaragoza y luego en Almería), las dinastías eslavas de Almería y Denia y los amiríes de Valencia se mantuvieron más tiempo en la "ortodoxia", acuñando moneda a nombre del califa de turno, real, falso o imaginario. Asimismo, recientemente ha sido analizada la pervivencia de la institución del califato a través de los hammudies de Córdoba y Málaga, lo que revela que durante gran parte del siglo XI se mantuvo la ficción califal ${ }^{3}$. En todo caso, el califato omeya les sirvió a todos los reinos taifas, sin excepción, de referencia y de medio de legitimación, aspecto perceptible en el terreno artístico ${ }^{4}$. Por ello, cabe preguntarse si esas posturas que se evidencian en la numismática ${ }^{5}$, "rupturismo" y "legitimismo", se manifestaron asimismo en las artes: ¿existieron unas taifas donde predominó la tradición artística califal durante más tiempo o con mayor preeminencia que en otras? ¿Se hizo con unos objetivos simbólicos específicos?

Los escritores andalusíes contemporáneos analizaron algunos de los motivos que condujeron a la debilidad y la desaparición de estos reinos, bien bajo la presión cristiana, bien con la conquista almorávide. Por un lado, se acusó a los soberanos de permitir el avance de los ejércitos cristianos en territorio musulmán sin llamar al ŷihād y pactando con los reyes infieles. En el aspecto religioso, denunciaban la desaparición del sentimiento piadoso en la sociedad, de los valores morales y la solidaridad entre la población, así como la actitud de indiferencia hacia los hombres de religión. Por último, criticaban la forma de gobierno de los reyes, la opresión y la fiscalidad ilegal impuesta a los musulmanes. Según Ibn Hazm, cobraban un impuesto personal o ŷizya que igualaba a los musulmanes con los dimmies. Este mismo autor e Ibn 'Arabī (padre, m. 1099) censuran igualmente a los mulūk al-tawâ' if por haber usurpado el poder, ejerciendo el gobierno de manera ilegítima, y por actuar como déspotas ${ }^{6}$.

3 M.D. Rosado Llamas, La dinastía hammūdi y el califato en el siglo XI, Málaga, 2008.

4 F. Clement, Pouvoir et légitimité en Espagne musulmane à l'époque des taifas ( $V^{\mathrm{e}} / X I^{\mathrm{e}}$ siècle), l'Imam fictif, Paris, 1997. M. Benaboud, "Asabiyya and Social Relations in al-Andalus during the Period of the Taifa States”, Hespéris Tamuda, 19 (1980-1981), pp. 5-45. Surge asimismo un interesante movimiento reivindicativo llamado šu'ubiyya que exaltaba las virtudes de la raza "eslava" y su "andalusismo" frente a la asumida superioridad árabe (Ibn García de Denia, por ejemplo), movimiento que ha sido considerado "nacionalista" y en ese sentido premonitorio de lo que estaba por llegar: los beréberes almorávides y almohades que muchos andalusíes vieron como extranjeros ocupantes. Mª J. RuBiera MATA, La taifa de Denia, Alicante, 1985, pp. 136-41.

5 M. AcIÉn cree ver también esas posturas en los estilos epigráficos de las diferentes taifas, en "Del estado califal a los estados taifas...", op. cit., pp. 496-501.

6 M. Fierro, "La religión. Unidad religiosa, prácticas y escuelas", Los Reinos de Taifas. Al-Andalus en el siglo XI, Historia de España dirigida por Ramón Menéndez Pidal, vol. VIII*, Madrid, 1994, p. 400; F. Clement, Pouvoir et légitimité..., op. cit., pp. 83-98. 
Como reacción a la situación de crisis, se acentuaron en la sociedad las preocupaciones morales y éticas y se desarrollaron ciertos aspectos espirituales. Así, aunque ya existían noticias de personajes dedicados a la oración y a la vida piadosa desde el siglo X, es en el siglo XI cuando la práctica del ascetismo adquiere mayor desarrollo y se generaliza la práctica del ribât, el culto o la visita de tumbas de personajes con reputación de santidad y las peregrinaciones a ciertos santuarios. Los retiros en rābițas estaban relacionados asimismo con la importancia que adquirió el yihäd o guerra santa contra los infieles, considerada por algunos andalusíes como una obligación más importante en al-Andalus que la peregrinación a La Meca. AlBakrī (m. 1094) consideraba al-Andalus "tierra de ŷihād y de ribāṭ, rodeada por el Este, el Norte y parcialmente por el Oeste de naciones infieles"”.

El arte taifa suele calificarse de barroco o manierista, unos términos usados a menudo con carácter peyorativo. El apelativo de "barroco" para el arte y la literatura del siglo XI sólo podría entenderse en el sentido de una "superación del molde clasicista" y no como recargamiento superfluo ${ }^{8}$. Un acercamiento a los géneros literarios de la época puede resultar útil a la hora de analizar y dimensionar ese nuevo estilo y vocabulario formal.

La importancia de la literatura en el siglo XI queda reflejada en la exaltación que hacen los poetas y secretarios cortesanos de las virtudes del cálamo, situándolo por encima de las espadas: "soy el eje en torno al que giran las dinastías, el instrumento de los logros de los reyes" ". Entre los géneros más apreciados y frecuentados estaba la prosa rimada, que mediante metáforas grandilocuentes, paradojas y expresiones burlescas elevaba los temas banales y cotidianos al rango de trascendentales y hacía sátira de los temas solemnes; junto a la prosa, el género más practicado fue la poesía panegírica, que servía fundamentalmente para exaltar las virtudes del gobernante, aunque también se evocaba en sus versos las glorias del pasado y las bellas ruinas de Córdoba (dando lugar a un género específico, el $u b i$ sunt $^{10}$ ), se describían

AL-BAKRī, Kitāb al-masalik wa-l-mamālik=Libro de los caminos y los reinos, trad. de E. Beltrán, Zaragoza, 1982, p. 39.

8 En ese sentido, tal y como recuerda J. Mohedano al estudiar la literatura del período, los movimientos de renovación en el arte suelen coincidir con procesos de crisis espiritual provocados, a su vez, por las crisis políticas y sociales. J. Mohedano Barceló, "Ibn Abdun de Évora, poeta, erudito y hombre de Estado, y la crisis espiritual del siglo XI en Al-Andalus", Bataliús II: nuevos estudios sobre el reino Taifa de Badajoz, número coordinado por F. Díaz Esteban, Badajoz, 1999, pp. 61-106.

9 "Epístola de la espada y el cálamo", escrita por Ibn Burd para Muŷāhid, rey de la taifa de Denia. Traducida por F. DE LA Granja en Maqamas y risalas andaluzas, Madrid, 1997, pp. $32-44$ (p. 36).

10 C. Robinson, "Ubi Sunt: Memory and Nostalgia in Taifa Court Culture", Muqarnas, XV (1998), pp. 20-31. A. Christys, "Picnic at Madinat al-Zahra", en Cross, Crescent and Conversion, Studies on Medieval Spain and Christendom in Memory of Richard Fletcher, ed. S. Barton and P. Linehan, The Medieval Mediterranean, vol. 73, Leiden-Boston, 2008, pp. 87-107. En un sentido más general trata el tema J. STEARNS, "Representing and Remembering al-Andalus: Some Historical Considerations Regarding the End of Time and the Making of Nostalgia", Medieval Encounters, vol. 15/2-4 (2009), pp. 355-374. 
las palmeras o se vilipendiaba a las chinches ${ }^{11}$. Frente al epicureismo dominante no faltaron muestras de estoicismo, de austeridad y renuncia, como decíamos más arriba, lo que también se manifestaba en los ambientes sofisticados de las cortes taifas, pese al preciosismo formal y a las palabras huecas que sirvieron de base a las críticas de sus rivales. La banalidad y la falta de moralidad fueron los argumentos esgrimidos por los almorávides en su campaña de desprestigio e incluso de damnatio memoriae llevada a cabo tras la desaparición de esos reinos.

Si hubo un género literario que destacó por encima del resto y que alcanzó entonces su esplendor ese fue el Adab. Las obras de Adab contienen gran parte de los saberes humanísticos, aunque sea de forma superficial. Correspondería al Trivium antiguo y medieval, que englobaba los estudios relativos a la elocuencia, la gramática, la retórica y la dialéctica. A ellos se añadían otros como la literatura, la poesía, la gemología o la astrología. El Adab proporcionaba los conocimientos enciclopédicos necesarios para desenvolverse en la corte y ejercer de cortesano, como kātib o secretario.

Los especialistas en la literatura árabe de la época ven en la actividad intelectual del siglo XI, centrada en el uso del $A d a b$, un conjunto de convenciones y de alusiones culturales que se convirtieron en una práctica social, en un sistema normativo y ético característico de un grupo: la élite ${ }^{12}$. En opinión de J. Mohedano, el Adab pasó a ser su medio de expresión y de comunicación, un «metalenguaje» que les identificaba como miembros de ese círculo selecto y que evidenciaba su posición y su nivel intelectual. Este lenguaje codificado resultaba incomprensible para los ajenos al grupo ${ }^{13}$. Aquellos personajes se encargaron de proporcionar a los reyes taifas los necesarios argumentos legitimadores, marcando los parámetros de soberano idea $1^{14}$. Asimismo, fueron esas élites, junto con las propias familias regias, los principales impulsores y los destinatarios de las obras de arte cortesanas ${ }^{15}$.

11 Dīwān de Ibn Suhayd al-Andalusí (992-1035), traducido por J. Dickie, El Dīwān de Ibn S̆́ $u h a y d$ Al-Andalusī. 382-426 $h=992-1035 C$, Texto y traducción, Córdoba, 1975, pp. 210 y 96 respectivamente.

12 T. Garulo, La literatura árabe de Al-Andalus durante el siglo XI, Madrid, 1998. Mª J. RuBIERA MATA, Literatura hispanoárabe, Alicante, 2004. P. Guichard y B. Soravia, Los reinos de taifas..., op. cit., pp. 287305 ("La cultura literaria y artística").

13 J. Mohedano Barceló, "Acerca de las funciones del Adab en la sociedad andalusí del siglo V/XI. Código críptico y élite cultural”, Al-Qantara, 25/2 (2004), pp. 503-537. La idea del lenguaje codificado en las cortes taifas también ha sido defendida por C. RoBINSON: los objetos de arte, la arquitectura y la ornamentación se sumarían a la literatura para crear esos ambientes del maylis cortesano donde "se evocaba la utopía de la eternidad": Palace Architecture and ornament in the courtly discourse of the muluk al-tawa'if: metaphor an utopia, Pennsylvania, 1995, I, p. 426.

14 Las obras de Adab suelen incluir un capítulo dedicado a la educación o "espejo de príncipes".

15 C. Robinson, "Love in the Time of Fitna: 'Courtliness' and the 'Pamplona' Casket", en G.D. ANDERSON \& M. Rosser-Owen, Revisiting Al-Andalus. Perspectives on the Material Culture of Islamic Iberia and Beyond, Leiden-Boston, 2007, pp. 99-112. 
En el círculo cortesano no había sólo secretarios $(k u t t a \bar{b})$, poetas y $\operatorname{literatos}^{16}$, aunque eran probablemente quienes más peso específico tenían; también había alfaquíes y tradicionistas, así como algunos cadíes, si bien éstos no estaban al servicio del soberano sino de la comunidad. Del mismo modo, debieron participar en las reuniones otro tipo de sabios como los astrónomos, los matemáticos, los filósofos y, por qué no, los muhandis o arquitectos-geómetras al servicio del soberano. Así parece revelarlo el epitalamio dedicado al maestro de obras de la Aljafería, el eslavo Zuhayr, escrito por Al-Ŷazzār, poeta panegirista del rey al-Musta'in, quien a buen seguro fue el instigador de la composición ${ }^{17}$. Del ambiente sapiencial de las cortes taifas eran partícipes los propios reyes que a menudo destacaron en esas ciencias: al-Mu'tamin de Zaragoza (108-1085) fue un notable matemático, al-Mu'tamid de Sevilla e Ibn Tâhir de Murcia fueron grandes poetas y 'Abd Allâh de Granada dejó un bello libro de memorias ${ }^{18}$. En consecuencia, podemos sospechar que los maŷlis cortesanos eran mucho más que reuniones o sesiones literarias donde se hacían lecturas poéticas amenizadas con copas de vino.

Los escenarios palatinos de los "maŷlis del saber" no podían sino reflejar plásticamente, cual espejo, ese lenguaje codificado de la corte, las palabras eruditas y ampulosas de los secretarios, los panegíricos y elegías de los poetas cortesanos, las reflexiones de los sabios sobre los fundamentos del universo y de la naturaleza. La arquitectura y su ornamentación parecen adoptar también un metalenguaje, un código comprendido por unos pocos, lleno de referencias cultas a la tradición andalusí y a Oriente, a la literatura y a las ciencias. Define J. Mohedano la literatura del XI como un cristal multifacetado donde se amalgaman y confunden deliberadamente los géneros para permitir percepciones múltiples y ambiguas: eso parece perseguirse en la arquitectura con el uso de técnicas tan diversas como el yeso, los vidrios y la pintura en un mismo espacio decorativo, con la combinación de líneas curvas y líneas rectas, con la fusión de geometría y vegetación, con los audaces y paradójicos juegos espaciales. Los objetos de procedencias diversas y exóticas (telas, marfiles, mármoles, vidrios y metales) completarían aquel sofisticado y erudito escenario ${ }^{19}$ (fig. 1).

16 Sobre el protagonismo de los kuttāb en las cortes taifas, P. GuICHARD y B. SORAVIA, Los reinos de taifas..., op. cit., pp. 265-286.

17 S. Barberá Fraguas, Dīwān de Abū Bakr al-ĞGazzār, el poeta de la Aljafería, edición bilingüe, introducción y notas, Zaragoza, 2005, pp. CCLXXVIII-CCLXXIX de la introducción.

18 La Taifa de Toledo fue famosa por las escuelas de astronomía y de botánica. IBN ṢĀ'ID AL-ANDALUSī, Historia de la filosofia y de las ciencias o Libro de las categorías de las naciones = Kitāb Tabaqāt al-umam, traducción, notas e índices de E. Llavero Ruiz, Madrid, 2000.

19 Dos estudios recientes ahondan en el significado de ciertos objetos realizados para el ámbito cortesano (amirí) y en la posible interpretación simbólica que tenían para el grupo de personas al que estaban destinados o ante el cual se mostraban: C. Robinson, "Love in the Time of Fitna: 'Courtliness' and the 'Pamplona' Casket" y M. Rosser-Owen, "Poems in Stone: the Iconography of 'Amirid Poetry, and its 'Petrification' on 'Amirid Marbles", ambos en G. D. Anderson \& Mariam Rosser-Owen, Revisiting Al-Andalus. Perspectives on the Material Culture of Islamic Iberia and Beyond, Leiden-Boston, 2007, pp. 99-112 y 83-98 respectivamente. 


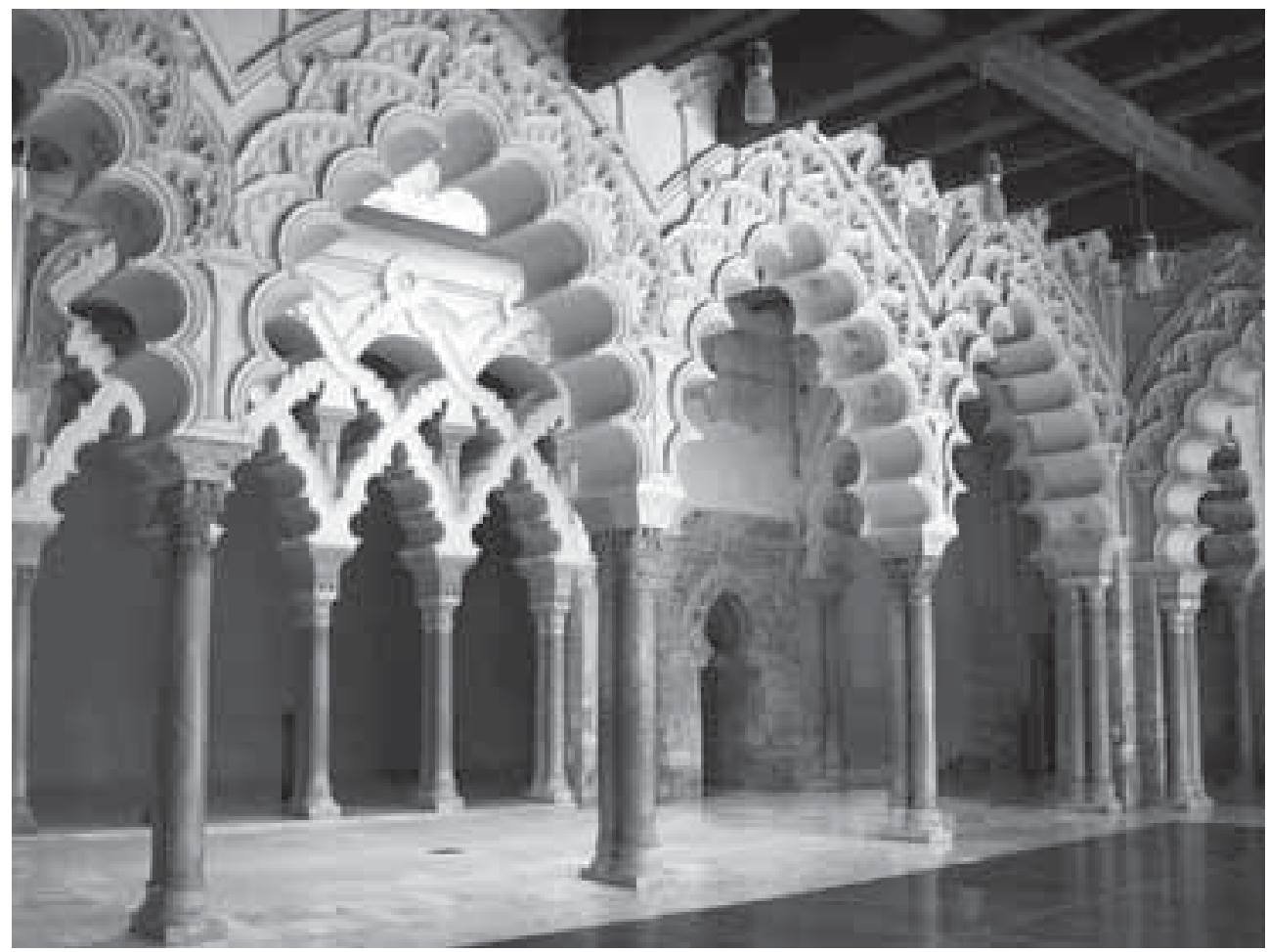

Fig. 1. Zaragoza. Palacio de la Aljafería. Arquerías del pórtico norte.

En este sentido, es muy atractiva la idea defendida por Emilio González Ferrín de que los reinos taifas podrían considerarse una suerte de ciudades-estado renacentistas italianas y los reyes taifas como los álter ego de las grandes familias de mecenas italianas ${ }^{20}$. No sólo es similar el ambiente humanístico y de mecenazgo artístico desarrollado en los dos ámbitos, sino incluso el predominio de la cultura urbana o el cambio de relaciones de poder con respecto a la clase religiosa más ortodoxa, como indicamos al principio.

A menudo se habla de la exclusiva dependencia formal del arte de las taifas respecto al arte califal (fundamentalmente del periodo amirí), aunque empobrecido éste desde el punto de vista material y expresivo. También suele aceptarse una cierta homogeneidad artística en el período ${ }^{21}$. Todo ello es matizable o está lejos de

20 E. GonzÁlez Ferrín, Historia General de Al Ándalus: Europa entre Oriente y Occidente, Córdoba, 2009, pp. 424-438; Id., "Al-Andalus: del mito asumido al Renacimiento", Miscelánea de estudios árabes y hebraicos, 58 (2009), pp. 383-405 (403-404). La idea fue ya sugerida por Ma . J. RuBIERA MATA en La taifa de Denia, op. cit., p. 153.

21 Véanse las interesantes matizaciones a estos conceptos que hace F. VALDÉs en «El arte de las primeras Taifas: una cuestión de cronología», La Península Ibérica y el Mediterráneo entre los siglos XI y XII (II): Almanzor y los terrores del milenio, F. VALdés (coord.), Codex aquilarensis, 14 (1999), pp. 167-185. 
la realidad. La escenografía desplegada en la arquitectura palatina que ha llegado hasta nosotros indica que, a pesar de la economía de medios, su impacto visual podía ser muy similar, en apariencia, al de los edificios califales. A la supuesta pobreza de materiales constructivos debemos contraponer la riqueza expresiva y la originalidad de los salones de la Aljafería de Zaragoza y del alcázar de Toledo. Por otra parte, las técnicas empleadas por los arquitectos del siglo XI ya se usaban en el siglo anterior, como el yeso tallado y la pintura mural, que aparecen abundantemente junto al mármol en la fase califal de la Mezquita de Córdoba ${ }^{22}$. También allí encontramos elementos arquitectónicos fingidos a través de la decoración ${ }^{23}$ (fig. 2).

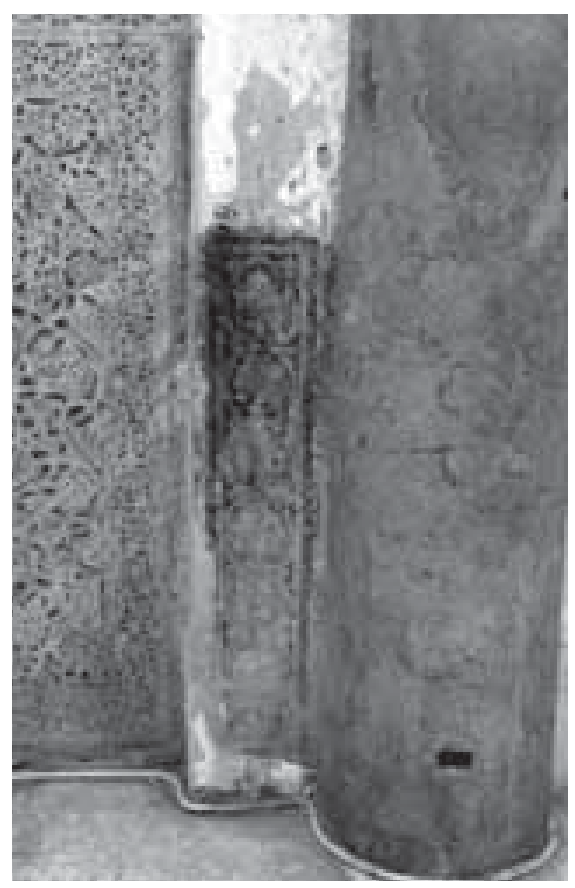

En cuanto a la denominada "orientalización" del arte andalusí en el período taifa, es un proceso que había comenzado a hacerse visible en el siglo $\mathrm{X}$ en las principales obras califales, como Madînat al-Zahrâ', la almunia conocida como Cortijo del Alcaide y la Mezquita de Córdoba, aportes examinados por el Dr. Christian Ewert, entre otros especialistas ${ }^{24}$. En todas ellas hay elementos ornamentales y tipologías derivadas claramente de la tradición artística abbasi ${ }^{25}$. En el siglo XI ese proceso de transformación del "clasicismo" omeya mediante la llegada de modelos, técnicas y objetos foráneos se acentuó.

En la Aljafería, palacio iniciado por alMuqtadir (1046-1081) entre 1065 y $1081^{26}$ y concluido por su nieto, al-Musta' in II (10831110), los arquitectos parecen plasmar sobre

Fig. 2. Mezquita de Córdoba, Detalle de los restos de pintura mural en la qibla, a la derecha del mihrab.

${ }^{22}$ Son de yeso la venera que cubre el mihrab y el friso de arquillos lobulados que le sirve de base.

${ }^{23}$ Las arquerías entrecruzadas que definen la capilla de Villaviciosa en la Mezquita de Córdoba son fingidas, pura decoración sobre un muro de sillería como muestran los dibujos publicados por M. GómEz MoRENo en El Arte Árabe Español hasta los Almohades. Arte Mozárabe, col. "Ars Hispaniae”, vol. III, Madrid, 1951, pp. 110 y 112 .

${ }^{24}$ Esa orientalización es negada, sin embargo, por autores como H. TERrasse, "Notes sur l'art des reyes de taifas", Al-Andalus (1965), pp. 175-180.

${ }_{25}$ C. EwERT, «El arte omeya andalusí en su última fase: El Cortijo del Alcaide», La Península Ibérica y el Mediterráneo entre los siglos XI y XII (II): Almanzor y los terrores del milenio, F. Valdés (coord.), Codex aquilarensis, 14 (1999), pp. 111-132. Id., «Precursores de Madinat al-Zahra. Los palacios omeyas y abbasíes de Oriente y su ceremonial áulico», Cuadernos de Madinat al-Zahra, 3 (1991), pp. 123-163.

${ }^{26}$ En 1065 adoptó el título de al-Muqtadir bi-llâh, que aparece recogido en las inscripciones del palacio. B. Cabañero Subiza, "La Aljafería de Zaragoza", Artigrama, 22 (2007), pp. 103-129. 
el papel complejos teoremas geométricos y matemáticos, incluso filosóficos (tres ciencias en las que destacó especialmente la Taifa de Zaragoza), que al alzarse se convierten en arquerías imposibles, trampantojos espaciales e insólitos juegos de volúmenes ${ }^{27}$. El propio nombre de al-Ya fariyya (en femenino) o al-Ya farî (en masculino, calificando a qasr, alcázar) podría ser un alarde de cultismo, una referencia a Oriente según Salvador Barberá. Ya fariyya no sería una alusión a la kunya del soberano, Abû Ya'far, sino a la ciudad palatina levantada por el califa abbasí Ya'far al-Mutawakkil en el siglo IX. Los poemas que describían aquella ciudad se hicieron famosos y varios palacios portaron ese nombre, incluso en la Córdoba califal, según el poeta Ibn Zaydûn ${ }^{28}$. El palacio de Zaragoza es llamado por el propio rey al-Muqtadir en un verso "palacio de gozo" (qasr o dâr al-surûr) y contenía un "salón dorado" (maŷlis al-dahab), calificativos ambos que emulan igualmente los nombres de palacios orientales y cordobeses ${ }^{29}$. Christian Ewert puso de relieve la deuda formal del palacio con la mezquita de Córdoba al tiempo que mostraba la originalidad de los espacios apocopados del palacio y de las tramas de $\operatorname{arcos}_{\text {entrecruzados }}^{30}$ (figs. 1 y 3 ).

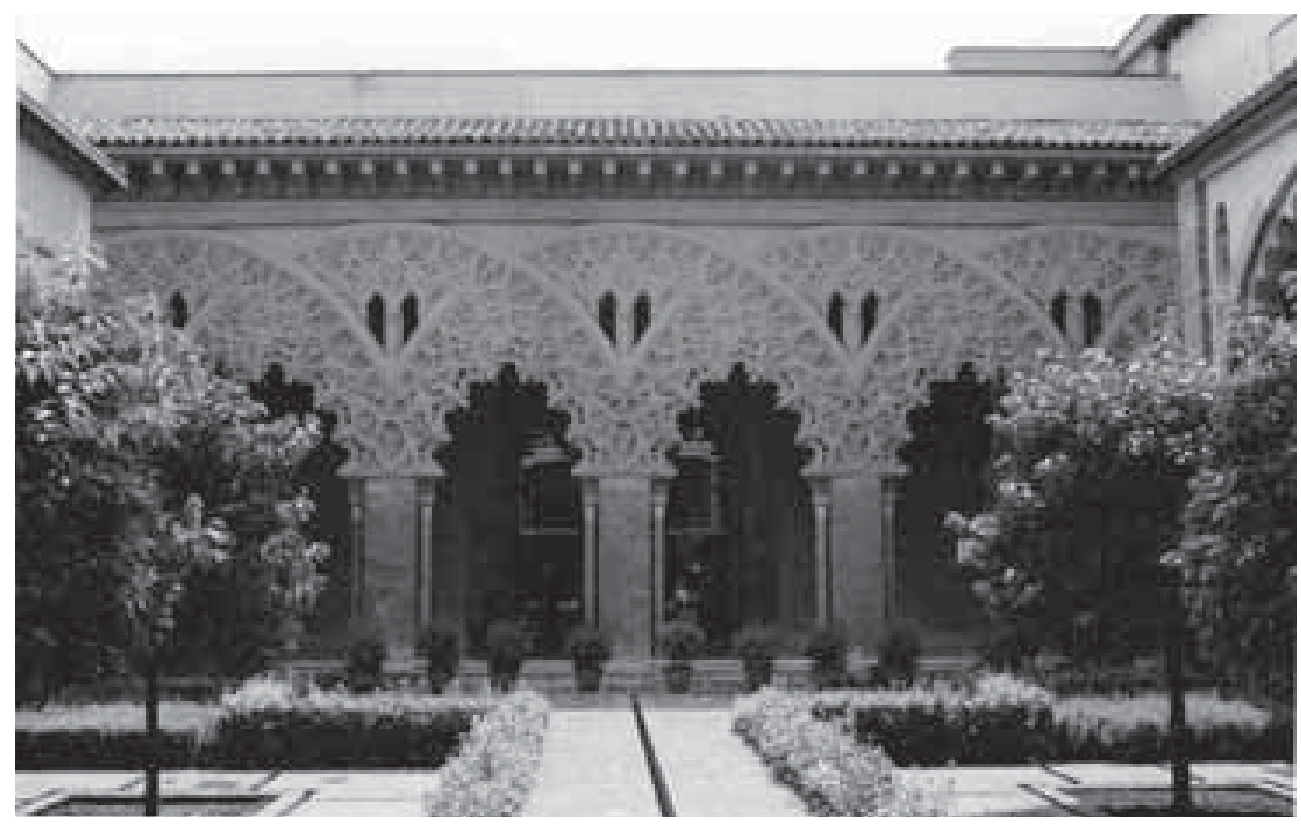

Fig. 3. Zaragoza, Palacio de la Aljafería, pórtico meridional.

27 Todo ello magníficamente estudiado por C. EWERT, Spanisch-islamische Systeme sich kreuzender Bögen. 3, Die Aljafería in Zaragoza, Berlín, 1978-1980 (Madrider Forschungen, 12).

${ }^{28}$ S. BARBeré, "La descripción de la Aljafería", capítulo de la introducción al Diwân, op. cit., pp. CCLXXII-CCLXXIII.

${ }^{29}$ Ibid., pp. CCLXXV-CCLXXVII.

${ }^{30}$ Sobre las influencias orientales en el palacio de la Aljafería, B. CABAÑERo, "La Aljafería de Zaragoza", op. cit., pp. 125-126. 
En Toledo se hallaron algunos restos del primitivo alcázar islámico en las últimas excavaciones practicadas en el interior del convento de Santa Fe, del Museo de Santa Cruz $^{31}$. Junto a una serie de estancias en torno a un patio, con zócalos pintados a la almagra, se encontraron (como materiales de relleno y por tanto carentes de un contexto arqueológico concreto) unos fragmentos de una arquería exenta provista de una riquísima decoración (en el intradós y en ambos frentes) de yesos pintados con motivos en relieve y con incrustaciones de vidrio o espejos. Además de los temas habituales de cetrería, aparecen unos animales fantásticos que tal vez se inscriban en un contexto astronómico, según sospechamos en una primera aproximación ${ }^{32}$. La extraordinaria riqueza técnica y la originalidad expresiva de estos yesos, al igual que la erudición y refinamiento de los temas representados contradicen claramente la idea de empobrecimiento, de recargamiento o de fiel continuidad con respecto al arte anterior. La decoración de vidrios incrustados resulta desconocida (al menos de momento) en el arte andalusí precedente y sin embargo hay indicios de que pudieron existir producciones similares en el norte de África en las mismas fechas y la técnica perduró en el Egipto mameluco ${ }^{33}$ (figs. 4, 5 y 6).

Estos dos ejemplos son buena muestra de la variedad del arte taifa. En cuanto a la herencia artística cordobesa, ésta coexistió con la bella maniera taifa y se convirtió en uno de los principales medios de legitimación de los nuevos gobernantes, que mostraban así su apego a la tradición de los fundadores del islam peninsular y su respeto a la ortodoxia, política y religiosa. La evocación legitimadora de las formas califales se aprecia con nitidez en los espacios religiosos: tanto en las mezquitas aljamas, renovadas por los reyes taifas siguiendo la tradición de emires y califas omeyas, como en los oratorios palatinos. En una de las primeras obras impulsadas por los tuyibies en Zaragoza, la ampliación de la mezquita aljama de la capital, se construyó un alminar inspirado en el alminar de la Mezquita de Córdoba pero introduciendo formas arquitectónicas y decorativas típicas del arte de finales del siglo $\mathrm{X}^{34}$. En cuanto a las mezquitas áulicas de este período que se han conservado, la primera impresión que causan es la de estar ante una diminuta copia de la macsura o del mihrab del gran santuario cordobés. Este fenómeno de emulatio puede observarse aún en períodos posteriores, y así, un siglo después, en la Mezquita de al-Qarawiyyîn de Fez (ca. 1135) los almorávides reutilizaron fustes y capiteles cordobeses en el muro de qibla con intenciones claramente simbólicas.

31 F. Monzón y C. Martín, "El antiguo convento de Santa Fe de Toledo. Recuperación de algunas dependencias de época musulmana", Revista del Instituto de Patrimonio Histórico Español y Bienes Culturales, 6 (2005), pp. 53-76.

32 En este momento, realizamos con Juan Carlos Ruiz Souza un análisis más detallado de estos restos.

33 M. Barrucand y M. Rammah (A. Shalem y J. P. Van Staëvel, eds.), "Sabra al-Mansuriyya and Her Neighbors during the First Half of the Eleventh Century: Investigations on Stucco Decoration", Muqarnas, 26 (2009), pp. 349-376. S. CARboni, "The Painted Glass Decoration of the Mausoleum of Ahmad ibn Sulayman al-Rifai in Cairo", Muqarnas, 20 (2003), pp. 61-84.

34 A. Almagro, «El alminar de la mezquita aljama de Zaragoza», Madrider Mitteilungen, 34, (1993), pp. 251-66. 

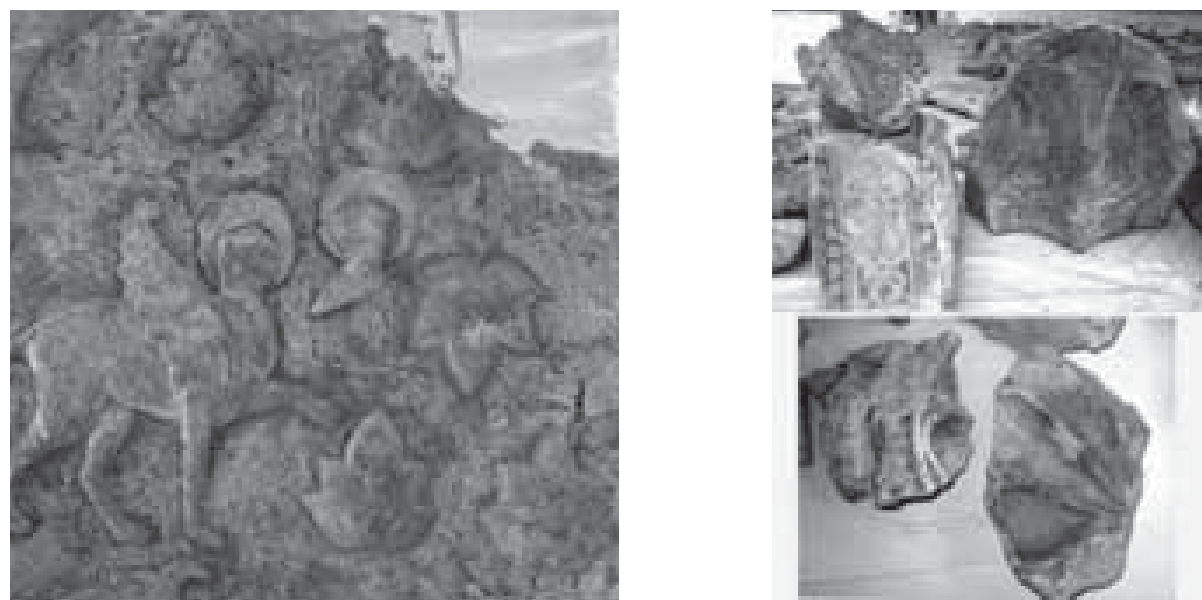

Fig. 4 y 5. Toledo, Convento de Santa Fe, restos del antiguo alcázar islámico.

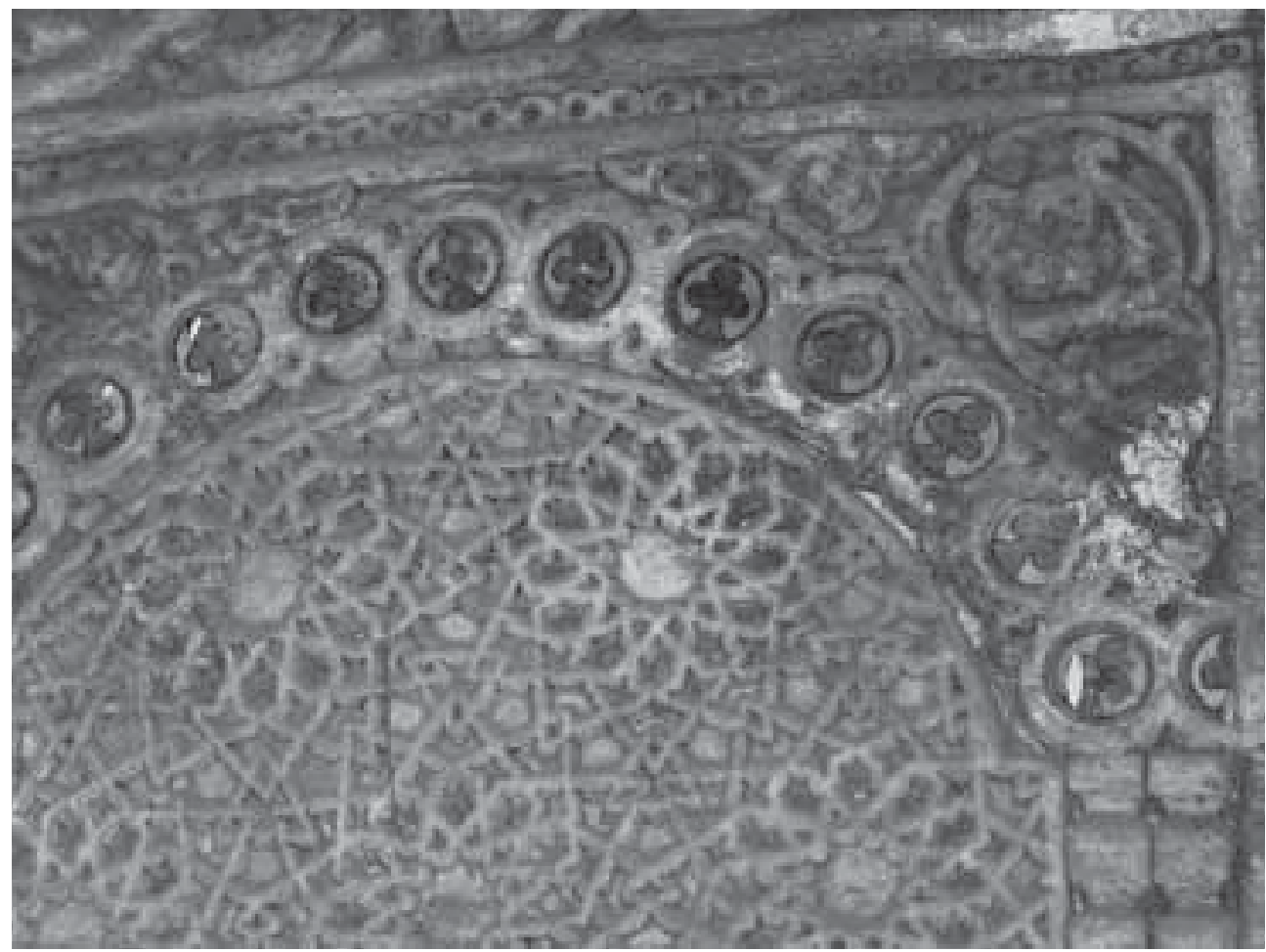

Fig. 6. El Cairo, Mansoleo Mameluco de Ahmad b. Suleyman al-Rifa'i. 
El oratorio del palacio de la Aljafería de Zaragoza (construido por al-Muqtadir entre 1065 y 1081) se inspira en el mihrab de la aljama de Córdoba: arcos de herradura para los accesos, un segundo piso abierto al espacio central mediante arquillos lobulados, todo ello cubierto de pinturas (lo que recuerda la disposición interior del mihrab cordobés), y una cupulita de gallones, dorada en origen, que sintetiza la venera cordobesa ${ }^{35}$ (figs. 7, 8 y 9).

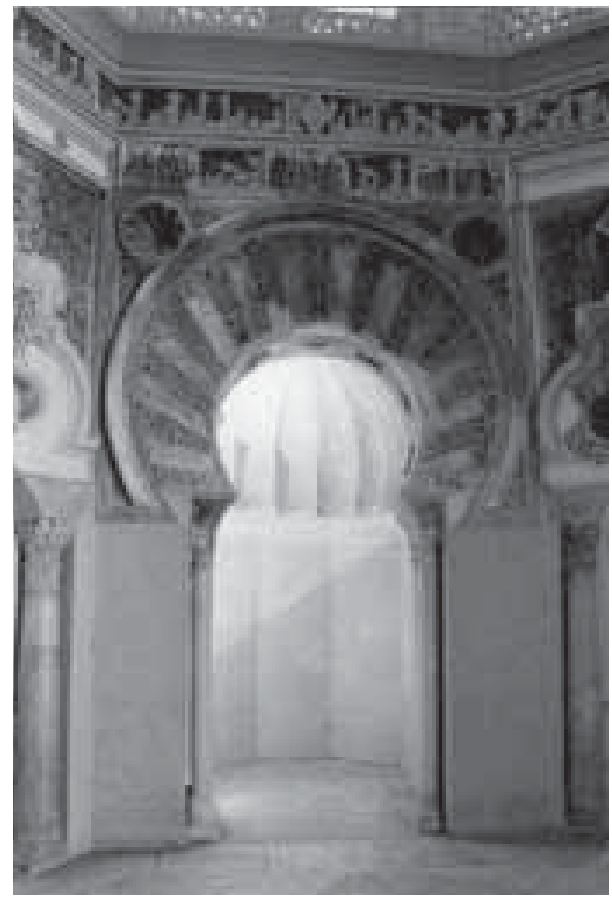

Fig. 7. Zaragoza. Arco de acceso al mihrab del oratorio del Palacio de la Aljafería.
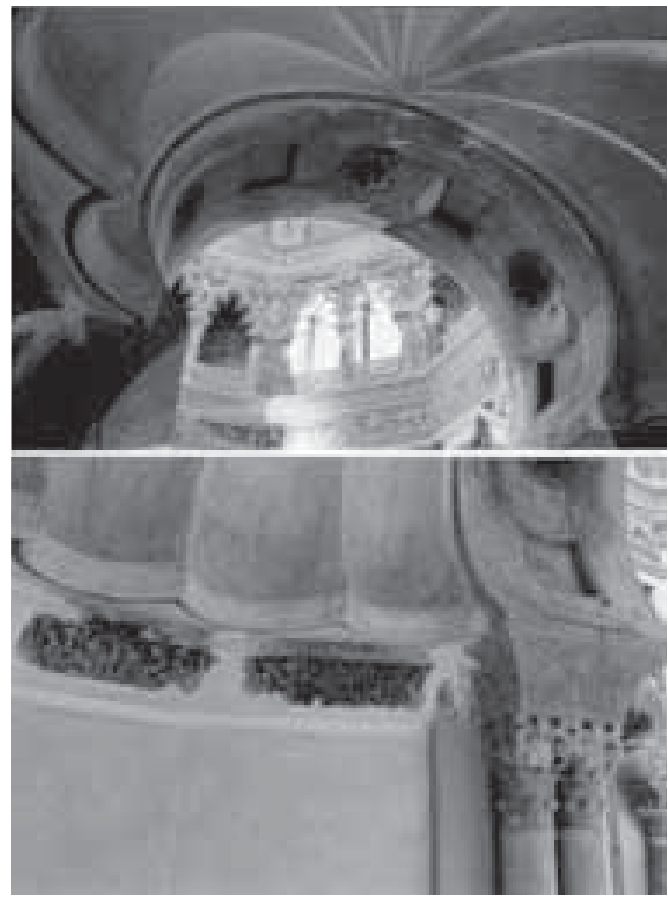

Fig. 8. Cúpula del oratorio del Palacio de la Aljafería.

La hoy llamada Capilla de Belén, seguramente oratorio del Alcázar de Toledo como hemos analizado en otras ocasiones, adopta la forma de una pequeña estructura cuadrada abierta por al menos tres de sus lados, como si se tratara de una macsura (la de la aljama cordobesa) independiente. Aunque ha perdido su decoración original, el uso de arcos de herradura, las fachadas de triple vano tan frecuentes en lo califal y su cúpula de nervios entrecruzados rematada en el centro por un cupulín, probablemente gallonado, evidencian la fidelidad a las formas cordobesas ${ }^{36}$. Este "clasicismo" del

35 C. Robinson, "Las artes de los reinos taifas", en J. Doods (ed.), Al-Andalus. Las artes islámicas en España, Madrid, 1992, pp. 46-61. Dice la autora con acierto que el edificio recuerda a una píxide califal.

36 S. Calvo Capilla, "La capilla de Belén del Convento de Santa Fe de Toledo: ¿un oratorio islámico?", Madrider Mitteilungen, 43 (2002), pp. 353-375. 


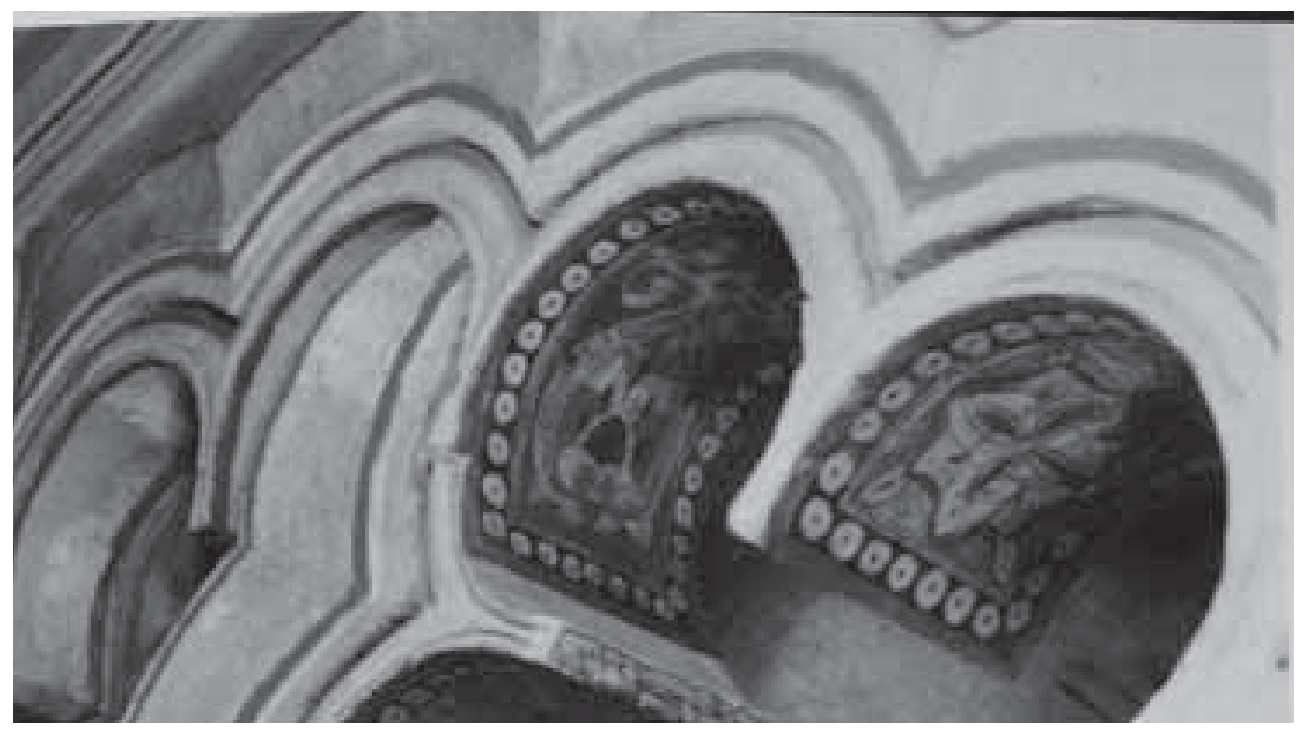

Fig. 9. Pintura mural de los arcos del segundo piso del oratorio de la Aljafería, Zaragoza.

ámbito religioso, signo de respeto a la ortodoxia y a la tradición, contrasta con la originalidad de los demás restos del palacio toledano (figs. 10 y 11).

El oratorio del alcázar de Murcia, en principio fechado entre finales del siglo XI y mediados del XII, se caracteriza asimismo por rememorar formas califales con el objetivo indudable de legitimar al nuevo gobernante ${ }^{37}$. Los restos de la mezquita y del panteón palatinos se hallaron recientemente bajo la iglesia de San Juan de Dios. Se trata de un conjunto excepcional, no sólo por su buen estado de conservación sino por la asociación de ambos elementos, la mezquita y la rawda, conocida a través de las fuentes árabes pero que hasta ahora contaba con escasos restos materiales $^{38}$. El oratorio es un espacio cuadrangular de aproximadamente $35 \mathrm{~m}^{2}$ con el mihrab (también cuadrado) abierto en el lado orientado al sureste ${ }^{39}$. Contaba con dos accesos, uno situado en el muro frontero al mihrab pero desplazado de su eje, y

37 Agradezco a D. Juan García Sandoval, director Museo de Bellas Artes de Murcia, la información que me ha facilitado, así como el acceso al edificio y a las obras de restauración que en él se han desarrollado. Los arqueólogos que lo excavaron son J.A. Sánchez Pravia y L.A. García Blánquez, que han publicado sus hallazgos en "Fulgor en el alcázar musulmán de Murcia. El conjunto religioso-funerario de San Juan de Dios”, en M. Parra Lledó (dir.), Las artes y las ciencias en el Occidente musulmán, Murcia, 2007, pp. 234251. El exquisito trabajo de los restauradores, Enma Zahonero y Jesús Mendiola, así como de Gabriel Lara, sirvió para poner de relieve las principales características de la decoración del mihrab.

38 Con un ejemplo tardío en la Alhambra de Granada (siglos XIV-XV).

39 No se ha hallado el muro de cierre noreste por lo que las dimensiones exactas no se conocen, si bien el nicho del mihrab, que tiene un notable tamaño $(0,80 \mathrm{~m} \times 1,22-24 \mathrm{~m})$ se hallaría aproximadamente en el centro del muro sureste, orientado a La Meca. 

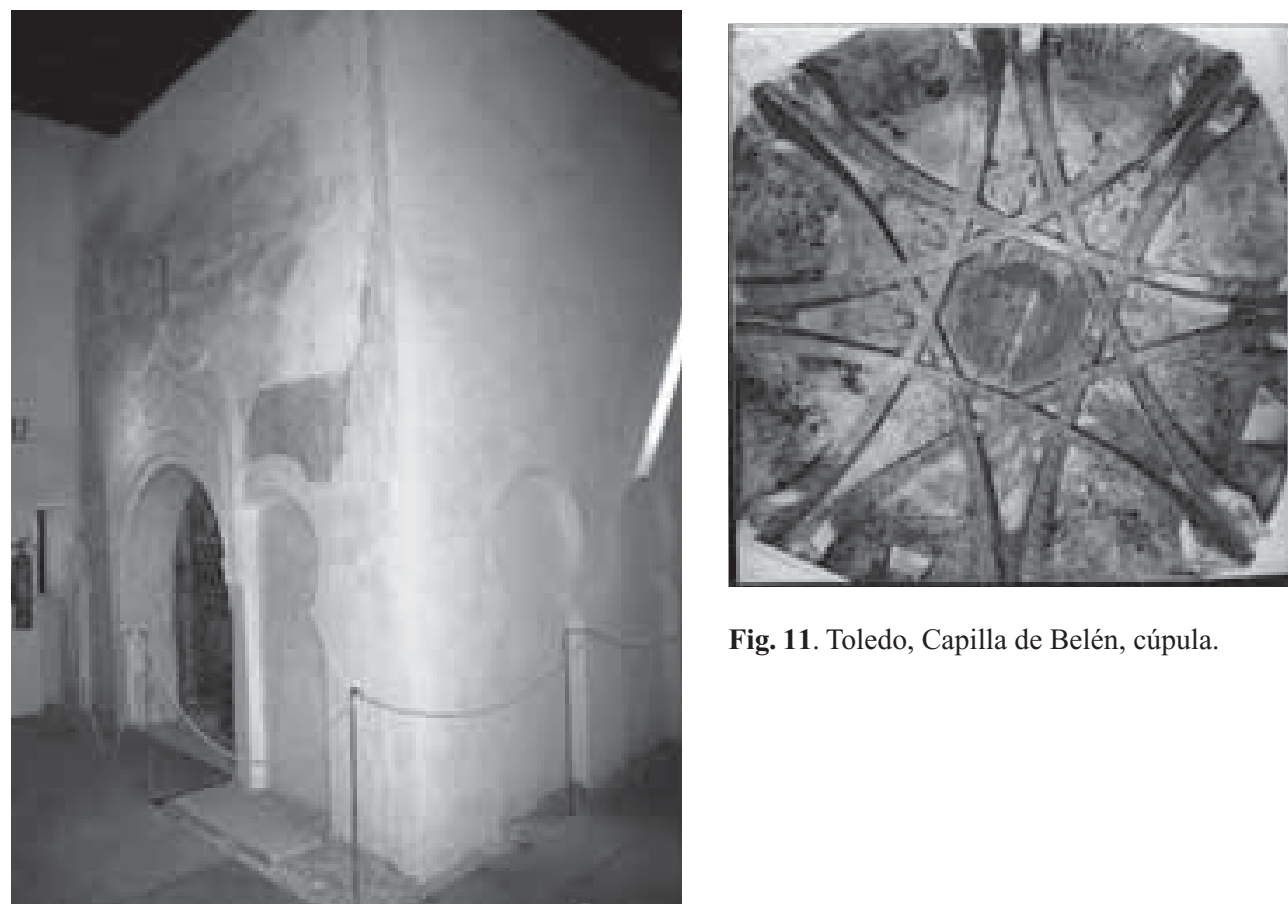

Fig. 11. Toledo, Capilla de Belén, cúpula.

Fig. 10. Toledo, Capilla de Belén, fachada exterior.

otro en el muro de qibla, a la derecha del nicho ${ }^{40}$. La estructura centralizada, ya sea planta cuadrangular, cuadrada u octogonal, es la habitual en los oratorios palatinos conocidos en al-Andalus (en la Aljafería de Zaragoza, la Capilla de Belén de Toledo o las mezquitas palatinas de la Alhambra de Granada) ${ }^{41}$ (fig. 12).

El arco de acceso al mihrab es de herradura y estaba pintado de vivos colores en su frente y su intradós. La rosca posee mayor anchura en la clave que en las impostas, es decir, un trasdós descentrado que, si bien estaba ya presente en los arcos califales, se hizo más acusado en el siglo $\mathrm{XI}^{42}$. A pesar a la variedad de arcos usada en la ar-

40 Las puertas en el muro de qibla están asociadas a un acceso privilegiado. Tratándose de un oratorio palatino, usado para el rezo diario por el soberano o gobernador y por su círculo más cercano (familiares y altos dignatarios), la entrada desde la qibla estaría reservada al propio soberano. Cerca de ella se encontró una pila de abluciones. Para la oración comunitaria del viernes, el gobernante seguramente acudía, como era usual, a la mezquita aljama de la ciudad, que, por otra parte, en Murcia quedaba muy cerca del alcázar.

${ }^{41}$ La planta cuadrangular del mihrab es asimismo muy común en al-Andalus: en la mezquita del Puerto de Santa María, Cádiz (siglo X-XI), el de la Aljama de Almería, hoy iglesia de San Juan (siglo X), en la mezquita del Alcázar de Jerez de la Frontera, también en Cádiz (siglo XII-XIII). En las mezquitas de la Alhambra de Granada la planta cuadrada queda achaflanada en los ángulos del fondo resultando un hexágono de lados irregulares. Al cubrir el nicho con una cúpula (sea ésta de arista, de gallones o de mocárabes) se dota al mihrab de un carácter singular, casi autónomo respecto al oratorio.

42 El descentrado puede apreciarse en los arcos toledanos de la Plazuela del Seco y Calle Bulas, o en los zaragozanos del mihrab de la Aljafería y del encontrado en Maleján. 


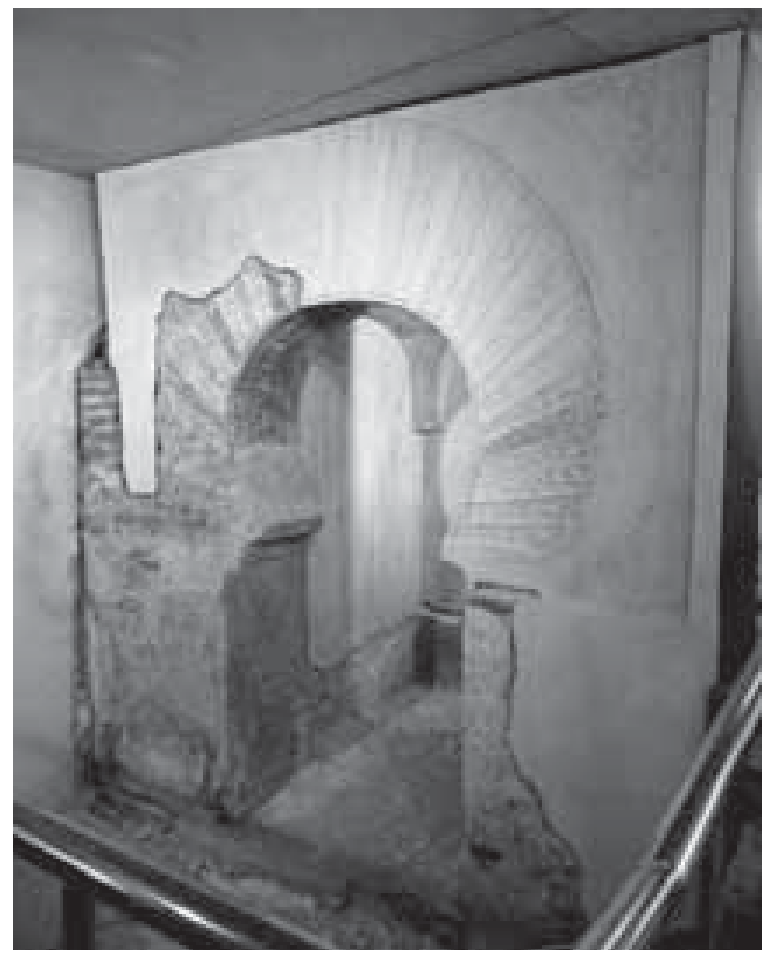

Fig. 12. Murcia, restos de la mezquita del alcázar de Murcia, bajo la iglesia de San Juan de Dios. Arco de acceso al mihrab. quitectura religiosa andalusí a partir del siglo XI, es significativo el predominio del arco de herradura en el acceso al mihrab, lo que denota la importancia que esta forma tenía como evocación de la tradición omeya y de los modelos clásicos. La ornamentación también se inspira directamente en el modelo de la aljama cordobesa: la alternancia de dovelas en relieve y pintadas, así como de los colores rojo y azul; $\mathrm{y}$ el rico repertorio de ataurique, consistente en roleos con piñas, hojas, flores y palmetas entre los tallos, conserva en parte el naturalismo califal. Otros rasgos indican una evolución de la decoración típicamente taifa, como el perfil lobulado del trasdós del arco, con lóbulos que saltan desde la mitad de una dovela a la otra. En las dovelas talladas el lóbulo se entrelaza con el ataurique, que lo llega a traspasar, lo que tiene sus más claros paralelos en los arcos del siglo XI como los ya citados del mihrab de la Aljafería de Zaragoza o Plazuela del Seco en Toledo ${ }^{43}$. Igualmente, la decoración del intradós del arco, donde el ataurique se superpone a una trama geométrica (estrellas de ocho puntas de fondo azul), se usa con frecuencia en la Aljafería de Zaragoza ${ }^{44}$. Un alfiz, ligeramente rehundido respecto al plano del muro de qibla y de las jambas, enmarcaba el arco del mihrab, aunque se han perdido las molduras que lo delimitaban (fig. 13).

Los restos del derrumbe han permitido conocer la forma de la cubierta del nicho del mihrab, un cupulín gallonado. Este tipo de cúpulas, perfectamente documenta-

43 El remate lobulado de las dovelas en su extremo exterior ya aparece en los triples arcos que decoran el alminar de la mezquita de Córdoba (siglo X), siempre con la misma disposición, los lóbulos saltan del centro de una dovela al de la otra. Sólo a partir de época almorávide, en los arcos de los mihrabs almohades y sobre todo en los nazaríes, los lóbulos se centrarán en las dovelas (cada lóbulo rematará una dovela) y se hará el festón mucho más visible.

44 En las tabicas de los modillones del gran salón de la Aljafería de Zaragoza encontramos algún diseño idéntico, salvo porque en la actualidad éste carece de policromía, B. CABAÑERO, "El palacio musulmán", en $L a$ Aljafería, Zaragoza, 1998, vol.1, p. 116. Unas franjas decoradas con entrelazos delimitan el intradós. 


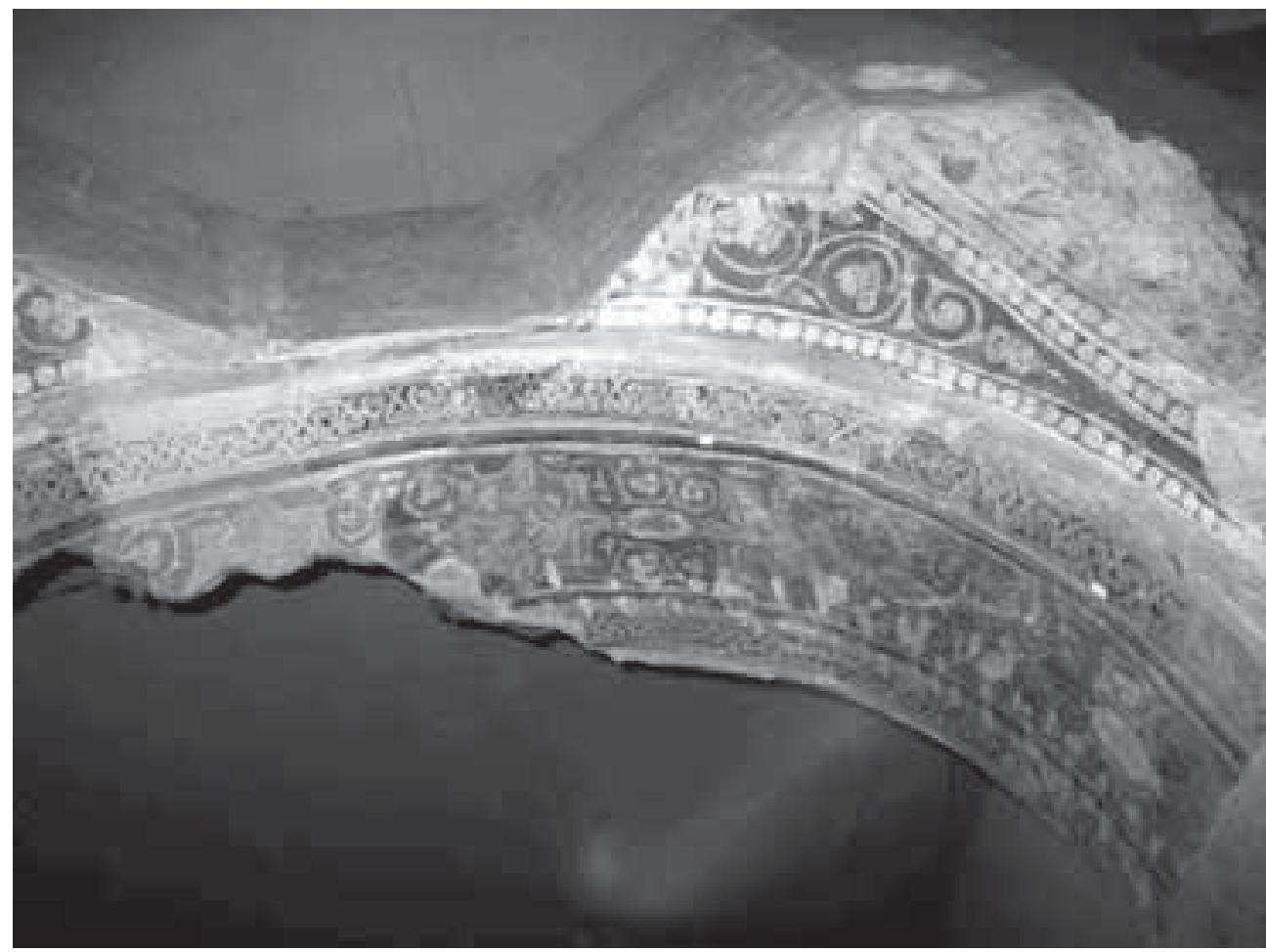

Fig. 13. Murcia, Oratorio del alcázar. Detalle del intradós del arco de acceso al mihrab.

do en varios mihrabs posteriores a la ampliación califal de la mezquita de Córdoba, responde muy probablemente a una simplificación de la venera que cubre el mihrab cordobés, cuya forma naturalista queda así sintetizada ${ }^{45}$. En el oratorio de la Aljafería de Zaragoza, como dijimos, se opta por una solución muy sencilla al tiempo que apegada a su modelo: el mihrab, de planta poligonal desde la base, se cubre con media cúpula de gallones, cuyo ápice o clave se coloca tras el arco de acceso al nicho, el mismo lugar que ocupa la charnela de la venera cordobesa ${ }^{46}$. En definitiva,

45 Este tipo de cúpulas gallonadas de pequeño tamaño sirvieron asimismo en época califal para cubrir un pequeño espacio, como el centro de las cúpulas de nervios entrecruzados, como se ve en las cúpulas de la ampliación de la Mezquita de Córdoba, de la segunda mitad del siglo X (cúpula de Villaviciosa, cúpula central de la macsura y laterales).

46 C. Ewert, Hallazgos islámicos..., op.cit., p. 415. En la mezquita aljama de Almería, el nicho, cuadrado en la base como el del oratorio murciano, se cubre con una cúpula gallonada que data de las fases prealmohades del mihrab, es decir, probablemente del siglo X (mezquita fundacional) o del XI. Según L. ToRRES BALBÁs, "La mezquita mayor de Almería", Al-Andalus, XVIII, 1953, pp. 412-430, esta cúpula era de piedra, revestida de yeso y dorada (como en la Aljafería) o pintada puesto que encontró restos de una imprimación roja. Entre los restos del alcázar taifa de Toledo, encontrados bajo el Convento de Santa Fe, hay varios fragmentos de yeso en forma de gallones con una decoración pintada muy similar a la de los gallones murcianos (roleos con flores y palmetas y cintas perladas), además de rosetas gallonadas y doradas (véase fig. $n^{\circ} 5$ ). 
el uso de cupulines gallonados sería de nuevo una muestra de apego a la tradición o herencia omeya (aquí, en el sentido religioso del término). Los gallones y las trompas de arranque de la cúpula del mihrab, asimismo pintados, presentan composiciones de roleos con palmetas, flores y hojas inscritas en cintas perladas, motivos que encuentran de nuevo paralelos cercanos en la Aljafería de Zaragoza ${ }^{47}$ y en el alcázar de Toledo ${ }^{48}$ (figs. 14 y 8).

Según lo publicado por los arqueólogos responsables de la excavación del conjunto de oratorio y rawda, Sánchez Pravia y García Blánquez, el edificio fue construido en el reinado de Ibn Mardanīš (11471172), el de mayor importancia en la historia de la Murcia islámica ${ }^{49}$. El argumento cronológico de mayor peso es, hoy por hoy, la datación de la

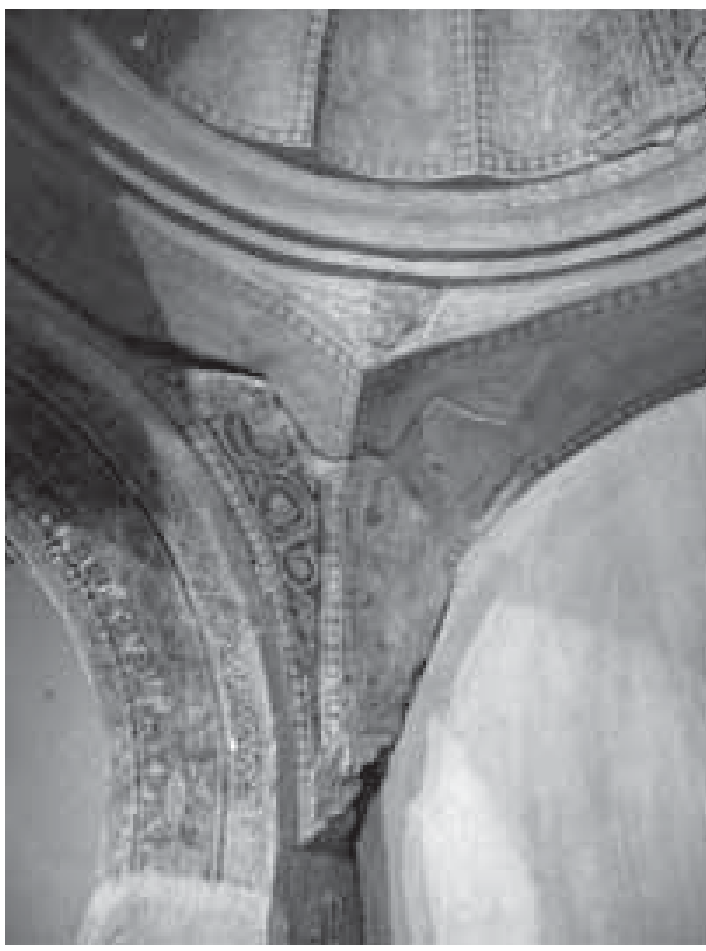

Fig. 14. Murcia, oratorio del alcázar. Interior del mihrab. muralla a la que se adosa el oratorio y la rawda, levantada en gran parte en época almorávide y mardanisí, los dos primeros tercios del siglo XII. Sin embargo, la cronología propuesta plantea dudas al analizar otros aspectos materiales y el vocabulario ornamental del arco y de la cúpula del mihrab que hemos analizado, más similares a los restos de los palacios taifas de Zaragoza y Toledo que a los de los palacios marda-

47 Las pinturas de la galería superior del oratorio, estudiadas por G. y C. EwERT, Die Malereien in der Moschee der Aljafería in Zaragoza, Mainz am Rhein, 1999.

48 Las molduras decoradas con grecas y con un tallo sinuoso que se remata en palmetas, ambas de marcado carácter clásico, recuerdan mucho todavía a los motivos califales (basas de las columnas de Madīnat al-Zahrā'). Sólo los fragmentos de yesos pintados con cintas perladas y roleos encontrados en el Convento de Santa Clara (procedentes posiblemente de una cúpula de mocárabes) son similares a la decoración del oratorio.

49 J.A. Sánchez Pravia y L.A. García Blánquez, "Fulgor en el alcázar...”, op. cit. Estos autores identificaron al menos dos fases constructivas en el oratorio, ambas, en su opinión, del periodo mardanisí; usan como elementos de datación unos restos de cerámica típica «de los siglos XI-XII», unos materiales y una técnica constructiva para el muro de qibla y nicho que, dicen, en Murcia «vienen fechándose en el siglo XII» y, por último, unos paralelos estilísticos con las yeserías de Santa Clara y Játiva, que a nuestro juicio no son tan claros. El edificio sufrió reformas hasta su total amortización; se supone que fue en época almohade cuando se encalaron los muros ocultando la decoración de la fachada del mihrab, si bien no hay datos que permitan asegurar ese punto. 
nisíe $^{50}$, lo que parece indicar una fecha anterior o un extraordinario apego a las formas de herencia califal con los referidos fines simbólicos e ideológicos ${ }^{51}$.

$\mathrm{El}$ azar ha querido que se conservaran tres oratorios palatinos de los siglos XIXII, mientras que nada sabemos, aparte de las citas indirectas en las fuentes escritas, de los que hubo en los palacios omeyas en los siglos IX y X. El catalogo de este tipo de mezquitas se completa con las del palacio de la Alhambra de Granada, de fecha posterior. El protagonismo de estos oratorios en el conjunto del palacio, por su ubicación estratégica en el caso de Zaragoza, junto a los salones de aparato, o de Murcia, con la rawda aneja, y por el carácter suntuoso y simbólico de su decoración, hace sospechar que no fue precisamente desapego religioso lo que caracterizó a estos monarcas taifas ${ }^{52}$. ¿Podrían ser estas mezquitas señal del aislamiento del soberano con respecto a la sociedad, que les hacía no participar de las oraciones comunitarias en la mezquita aljama? ¿O bien serían signo de recogimiento, usadas incluso como lugar de retiro espiritual?

Recordemos lo dicho anteriormente sobre la intensificación de las experiencias ascéticas y la generalización de la práctica del ribật. El retiro realizado en rabitas servía a un doble propósito religioso, alcanzar la pureza espiritual llevando una vida ascética y al mismo tiempo combatir en defensa del Islam $^{53}$.

50 Del segundo tercio del XII son las yeserías del palacio de Pinohermoso (Játiva), del Castillejo de Monteagudo y del Convento de Santa Clara la Real (en Murcia). Los fragmentos con cintas perladas y roleos de Santa Clara (procedentes posiblemente de una cúpula de mocárabes) son los más similares a la decoración del oratorio. El ataurique almorávide, de la qubba de la mezquita de Alî b. Yusûf y del almimbar de la Kutubiyya (1125-1130), se aleja de los motivos del oratorio.

${ }^{51}$ En el siglo XI, los Banū Ţāhir (1038-1079) gobernaron Murcia de forma prácticamente autónoma, aunque estuvieran bajo la protección (y control nominal) de los reyes de las taifas de Almería, Valencia y Denia. El segundo y último de los gobernantes, Abū 'Abd al-Rahmān ibn Țāhir (de 1063 a 1079), fue uno de los personajes más cultos y con más dotes literarias del momento, además de bon vivant y apreciado por sus contemporáneos. Algunos tramos de la muralla se han datado en el siglo XI. Le siguieron sesenta años de gobierno almorávide, desde 1091 (tras unos años de accidentado control sevillano). El gobernador, Muhammad b. 'Aiša, hijo del emir Yūsuf b. Tašufīn y sobresaliente jefe militar, lanzó desde 1097 algunos ataques contra los territorios en posesión del Cid e hizo ampliar la mezquita aljama de Murcia. En el terreno cultural, y por tanto también en el artístico, el período almorávide inicial no supuso una ruptura con la tradición taifa: muchos literatos cortesanos, visires y secretarios se mantuvieron en sus puestos junto a los nuevos gobernadores almorávides como Abū Ŷa'far Ahmad b. Ŷurŷ. Ma .J. ViguerA, Los reinos taifas..., op. cit., pp. 91-94 y T. GARULO, "Un poeta menor de siglo V/XI: Abū Ŷa ‘far Ahmad b. Ŷrŷ”, Sharq al-Andalus, nº 10-11 (1993-1994), pp. 403-22.

52 Recordemos que una de las primeras acciones públicas de los reyes taifas fue la ampliación de la mezquita aljama de la capital del reino, manteniendo la costumbre de la dinastía omeya en al-Andalus y de la mayor parte de los soberanos del Dār al-Islam.

53 M. ArCas CAMPOY, "El criterio de los juristas malikíes sobre ciertas prácticas rituales en el ribat. AlAndalus y Norte de África", Miscelanea de Estudios Árabes y Hebraicos, 55 (2006), pp. 37-48. En el siglo XI se encuentra mayor número de noticias sobre personajes dedicados a la vida ascética (zuhhâd), hombres de religión y santos que viven retirados del mundo. Paralelamente, y como reflejo de esa corriente, también se produce un florecimiento de las composiciones de tipo piadoso y ascético. Con todo, señala M. Fierro que no es posible afirmar categóricamente que este período esté caracterizado por los movimientos ascéticos y sufíes. M. Fierro, "Unidad religiosa", op. cit., pp. 405. Id.., "El Sufismo", en El Retroceso territorial de al-Andalus. Almorávides y Almohades, H.E.M.P., vol. VIII**, 1997, pp. 483. 


\section{Objetos de lujo y contactos con Oriente}

La tradición cordobesa y el "clasicismo" del arte califal no siempre se debilitaron en su proceso de disgregación y dispersión por los reinos taifas. No sabemos exactamente cuál fue el papel jugado en el arte del siglo XI por la diáspora de los talleres de artesanos y artistas cordobeses, cuyo fenómeno hoy se juzga sobrevalorado, pero que indudablemente existió, como existió el trasvase de sabios y literatos. Ciertamente, algunos talleres de manufacturas de lujo que tenían carácter de monopolio oficial decayeron, como los marfiles, aunque probablemente la causa se relacione con el corte del suministro de la materia prima, el marfil que llegaba de África, a la caída del califato cordobés. En cambio, talleres como los que fabricaban tejidos de lujo y de tiraz sufrieron un desarrollo sin precedentes, abriéndose el mercado a todo tipo de clientela, y por tanto desbordando el reducido círculo oficial al que habían estado destinados hasta entonces. Los centros de producción más importantes de aquellos paños con bandas bordadas, de alfombras y de tapices pasaron a ser Murcia, Málaga, Almería ${ }^{54}$.

Las tipologías y las formas decorativas se transformaron y renovaron para adaptarse a los nuevos mecenas (entre ellos, las cortes taifas), y para responder a las nuevas exigencias simbólicas y propagandísticas. Las artesanías de lujo y los objetos preciosos traspasaron igualmente las fronteras y se filtraron de forma masiva en los reinos cristianos peninsulares ${ }^{55}$, no sólo a través de la venta y donación del producto del botín obtenido en los saqueos por las tropas mercenarias cristianas, o del pago de parias en especie, sino también como resultado de los intensos intercambios comerciales ${ }^{56}$. Las taifas producían artesanías de alta calidad muy demandadas en los mercados de los reinos cristianos de tal manera que una parte de las parias pagadas por los reinos musulmanes, según un estudio de J. M. Lacarra, volvía a ellos mediante la venta de sus productos ${ }^{57}$. El comercio y la industria de al-Andalus vivieron una época de apogeo en este siglo XI lo que evidentemente permitió el sostenimiento del sistema de vasallaje y de los propios reinos.

\footnotetext{
54 Según el geógrafo del siglo XI al-'Udr en la provincia de Murcia había "excelentes talleres de ţirāz e industrias exóticas de alfombras, de tapices [...]”, trad. de E. Molina López, "La Cora de Tudmir según al-“Udrī (s. XI)”, Cuadernos de Historia del Islam, 3 (1972), p. 70. Al-Rušāţī (s. XII), al-Idrīsī (s. XII) o al-Maqqarī (s. XVII), entre otros, aluden a los famosos telares de Almería y a su puerto, al que acudían barcos de Alejandría y Siria: textos recogidos en J. LiRola, Almería andalusí y su territorio. Textos geográficos, Almería, 2005, pp. 49, 61, 199-203.

55 Tomo prestada la expresión “filtración de al-Andalus” de E. GonzÁlez Ferrín, Historia General, op. cit.

56 J.C. Ruiz SouzA, «Botín de guerra y tesoro sagrado», Maravillas de la España Medieval. Tesoro Sagrado y Monarquía. León, 2000, pp. 31-39.

57 J.M. LACARRA, «Aspectos económicos de la sumisión de los reinos de taifas (1010-1402)», Homenaje a J. Vicéns Vives, vol. I, Barcelona, 1965, pp. 255-277. Es sobradamente conocida la anécdota de Alfonso VI "despreciando" las telas que le ofrece Abd Allāh: El siglo XI en $1^{a}$ persona: las «Memorias» de 'Abd Allāh, último rey Zīrī de Granada destronado por los Almorávides (1090) [= Al-Tibyān 'an al-hāadit_a al-kā'ina bidawlat Ban̄ Zīrī fì Garnāta], traducción de E. Leví-Provençal y E. García Gómez, Madrid, 1993, p. 160.
} 
A todo ello se sumaron la subasta y el expolio de los tesoros del califato andalusí, a comienzos del siglo XI, un acontecimiento muy similar al documentado cincuenta años después en El Cairo fatimí. Entre 1009 y 1010 se produjo la venta de los bienes califales, el arrasamiento de Madīnat al-Zahira y el saqueo de Madīnat al-Zahrā’ y del Alcázar de Córdoba por las tropas beréberes y el "populacho", según las noticias recogidas por Ibn "Idāāri ${ }^{58}$. A éstas se suma otra de gran interés transmitida por Ibn al-Jaţîb, que permite documentar la venta de los bienes califales por el propio soberano al inicio de las revueltas de la fitna en Córdoba:

[En 1010, Hisam II b. al-Hakam] se vio precisado de dinero y sacó de su alcázar todo lo que tenía de alhajas preciosas, tesoros, vajillas de plata y oro, telas, muebles, hasta los libros, los armarios, el menaje, los hornos, incluso las medicinas y los fármacos para curar. ... Reunió [después] a la gente en el Alcázar y se quejó de la carestía y de la escasez. Ellos le mostraron su incapacidad para tributar más... ${ }^{59}$.

Por su parte, la crisis del estado fatimí provocó efectos parecidos:

Las alcaicerías y los zocos de El Cairo están llenos de objetos provenientes del palacio del sultán, llevados allí y vendidos a la población; los beneficios fueron usados como salario de los soldados turcos y otros en el año 460H/1068-69 [...] Ciertas personas me han informado de que ricos mercaderes han transportado algunos de esos preciados bienes a otras ciudades, donde se convirtieron en soberbios ornamentos y enriquecieron los tesoros de sus soberanos, y que les sirvieron también de decoración y de objetos de ostentación en sus reinos. ${ }^{60}$

La consecuencia inmediata fue que los mercados del Mediterráneo quedaron inundados de objetos de lujo procedentes de los palacios califales de Córdoba, subastados y saqueados entre 1009 y 1010 y de los palacios fatimíes de El Cairo, vaciados entre 1061 y 1069 . La almoneda cordobesa y después la fatimí fueron, parafraseando a Jonathan Brown, las "Almonedas del siglo" en el Mediterráneo ${ }^{61}$.

Esta venta del tesoro fatimí y, sobre todo, los intensos contactos comerciales de los reinos taifas con Oriente y el norte de África, pudieron ser la vía de llegada desde el resto del mundo islámico de los numerosos aportes artísticos y culturales que enriquecieron al-Andalus en el siglo XI. Los documentos de la Geniza de la Sinagoga de El Cairo (Fusțâț) mencionan la presencia andalusí en Egipto y en el puerto de Adén (Yemen), desde donde mantenían lucrativos negocios con la India en el siglo $\mathrm{XI}^{62}$. Las mercancías (tejidos, en concreto) y los mercaderes de la Península llegaron a puertos de

58 IBN 'ID̄̄ēî, al-Bayân al-Mugrib fii ajbâr al-Andalus wa-l-Magrib (vol. III) = La caída del Califato de Córdoba y los Reyes de Taifas, F. Maíllo SAlgado (trad.), Salamanca, 1993, pp. 61-62, 66-67, 89 y 98.

59 IBn Al-JațīB, A 'mal, trad. M. D. Rosado Llamas, op. cit., p. 285.

${ }^{60}$ Book of gifts and rarities $=$ [Kitāb al-Hadāyā wa al-Tuhaf], selección y traducción de G. AL-HiJuĀWĪ Al-QAdDūmī, Cambridge (Mss), 1996, capítulos 83 y 96.

61 J. Brown, El triunfo de la pintura: sobre el coleccionismo cortesano en el siglo XVII, Madrid, 1995, p. 59 y ss.

62 A.L. Udovitch, "Fatimid Cairo: Crossroads of World Trade — From Spain to India," in M. BARRUCAND (ed.), L'Égypte fatimide, pp. 681-691. S. D. GoITEIN, A Mediterranean Society: the Jewish Communities of the Arab World as Portrayed in the Documents of the Cairo Geniza, University of California Press, reed. 1993. 
Bizancio como el de Tesalónica, según recoge el diálogo satírico “Timarion”, del siglo $\mathrm{XII}^{63}$. Sabemos de comerciantes de Badajoz y de Toledo, así como de peregrinos de Madrid que se daban cita en Fustăţ (El Cairo) ${ }^{64}$. En ese siglo, fueron famosos los barcos de Ibn Muŷāhid, rey de la taifa de Denia, que hacían la ruta comercial entre Denia, Baleares, Egipto, Siria y otros puertos orientales ${ }^{65}$. También eran conocidos los dianenses por ejercer la piratería en las costas del sur de Francia y de Italia ${ }^{66}$.

Ibn al-Jaţīb e Ibn 'Idāāī recuerdan que el rey de Denia, 'Alī b. Muŷāhid al-'Amirí también estableció relaciones de buen entendimiento con los califas fatimíes, enemigos de al-Andalus hasta la desaparición del califato omeya. Muŷāhid envió en 105455 un barco cargado de provisiones a Egipto, un país asolado entonces por la hambruna y la peste, y el califa al-Mustanşir le devolvió el barco cargado de "tesoros"67. El autor anónimo del Libro de los Regalos y las Rarezas, un inventario de los tesoros fatimíes escrito poco después de la quiebra del Estado fatimí (producida entre 1061 y 1069), documenta otro regalo enviado por el rey de Denia en el año 1060:

En el año 452H/1060, Ibn Muŷāhid, el gobernante de al-Andalus, hizo un regalo a alMustanşir bi-Allāh valorado en cientos de miles de dinares. Incluía un collar de perlas valorado en diez mil dinares. También contenía los tejidos de seda pura con hilos de oro más bellos y asombrosos. El mensajero que llevó el regalo murió el mismo año. [...]Mandó un regalo bello y de gran valor de los productos de su tierra: muebles, telas, además de otras preciosas y valiosas cosas. Le ofreció con esto unas barritas de coral perfectamente rectas, tan finas como flechas y tan rojas como cálamos, nadie ha visto nunca nada semejante. ${ }^{68}$

Estos contactos, muy poco conocidos, son de gran trascendencia para explicar ciertas relaciones entre el arte fatimí y el andalusí en el siglo XI, asunto sobre el que queda mucho por investigar. Concluimos con una serie de obras de origen o de sabor oriental que abren sugerentes interrogantes y vías de estudio del arte de los reinos taifas.

${ }^{63}$ S. Calvo Capilla, "Viajes por el Mediterráneo entre los siglos VIII y XII: tras los pasos de los viajeros andalusíes, fatimíes y bizantinos», en Caminos de Bizancio, coord. por M. CoRTÉs ArRESE, ¿lugar de edición?, 2007, pp. 157, n.49.

${ }^{64}$ F. VALDÉs, "Datos sobre el comercio peninsular durante las primeras Taifas: El Reino de Badajoz", $V$ Semana de estudios medievales: Nájera, 1 al 15 de agosto de 1994, coord. por J. I. DE LA IGLESIA DuARTE, Nájera, 1995, pp. 167-174.

65 O.R. Constable, Comercio y comerciantes en la España musulmana. La reordenación comercial de

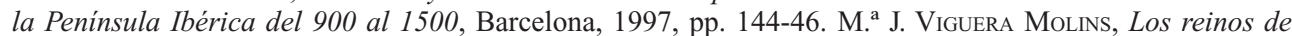
Taifas..., op.cit., p. 85.

${ }^{66}$ Con los condes catalanes habían llegado a ciertos acuerdos de no agresión y uso comercial de los respectivos puertos. T. Bruce, "An Intercultural Dialogue between the Muslim Taifa of Denia and the Christian County of Barcelona in the Eleventh Century", Medieval Encounters, vol. 15/1 (2009), pp. 1-34.

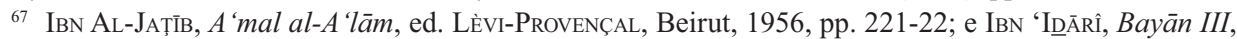
ed. G. S. Colin \& É. LÉvi-Provençal, Bayrūt, 1970, p. 228. Traducción de F. Maíllo, La caída del Califato de Córdoba y los Reyes de Taifas, Salamanca, 1993, p. 191.

${ }^{6}$ Book of Gifts and Rarities, trad. AL-QADDŪMĪ, op. cit., capítulos 83 y 96. Es curiosa la noticia que proporciona el rey zirí de Granada, 'Abd Allāh, sobre la existencia de inventarios de los “tesoros” y bienes guardados en el alcázar, inventarios demandados por los almorávides al conquistar el reino granadino para comprobar que los miembros de la familia regia y de la corte no se llevaban nada consigo, El siglo XI en $1^{a}$ persona, traducción de E. Leví-Provençal y E. García Gómez, op. cit., p. 273. 
Entre los objetos fatimíes hallados en la Península es interesante señalar la presencia de dos arquetas, una de plata guardada en el Tesoro de San Isidoro de León y otra de marfil que porta el nombre de Al-Mu'izz en el Museo Arqueológico Nacional. La arqueta de San Isidoro es la única caja fatimí de plata de este tipo conocida. La inscripción indica el destinatario, el visir Şadaqa ibn Yūsuf, que desempeñó su cargo entre 1044 y 1047 en la corte del califa fatimí al-Mustanşir bi-llāh (r. 1036-1094). La arqueta de marfil del Museo Arqueológico Nacional procede del monasterio de San Zoilo de Carrión de los Condes (Palencia), donde se conservan asimismo importantes tejidos orientales ${ }^{69}$. Fue fabricada en al-Manşuriyyah (Túnez) por un artesano llamado Muhammad (o Ahmad) al-Jurasan̄i, según reza la inscripción, y ha de datarse antes de 972, fecha en que al-Mu'izz se trasladó a El Cairo ${ }^{70}$. Dado que ambas fueron realizadas para personajes de la corte fatimí podríamos sospechar que proceden de su tesoro, si bien ignoramos cómo y cuándo llegaron a al-Andalus (fig. 15).

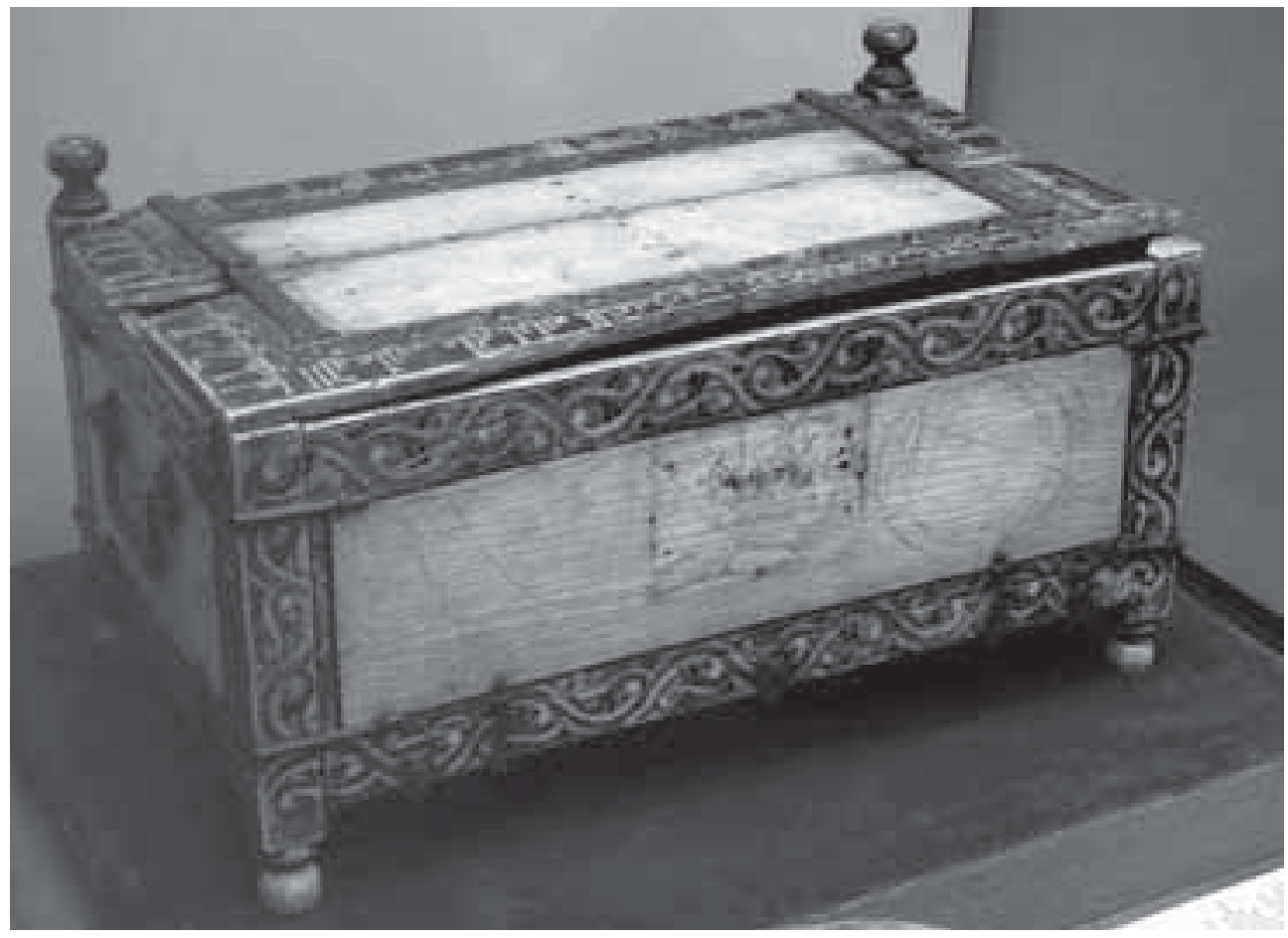

Fig. 15. Arqueta fatimí de marfil conservada en el Museo Arqueológico Nacional. Madrid.

69 J.L. Senra Gabriel y Galán, «Dos telas islámicas encontradas en el monasterio de San Zoilo de Carrión de los Condes», Goya, 2004, pp. 332-340.

70 M.A.N. $n^{\circ}$ inv. 50887. S. CAlvo Capilla, " $n^{\circ}$ 23. Arqueta de plata”, Maravillas de la España medieval. Monarquía y Tesoro Sagrado (San Isidoro de León, 2000-2001), Madrid, 2001, p. 114. Son asimismo numerosas las piezas de ajedrez y otros objetos de cristal fabricados en el Egipto fatimí que se han conservado en España: M. CASAmar y F. Valdés Fernández, “Arratomas irakes”, Homenatge Jesús Tarragona, Lérida, 1996, pp. 67-88. 
También de Egipto proceden los bronces de un tesoro hallado en la calle Historiador Palau de Denia. En el conjunto hay una serie de piezas, como los candelabros, de indudable origen fatimí y otros de procedencia más remota, como los esencieros de forma acampanada fabricados probablemente en la zona de Persia (Nishapur), con cronología de los siglos VIII a X. Todos ellos han sido puestos en relación con los intercambios citados más arriba entre Denia y los puertos del Egipto fatimí ${ }^{71}$.

Originaria de Mesopotamia sería la vasija cerámica encontrada en las estructuras palatinas excavadas en el convento de Santa Fe de Toledo, el lugar donde se levantaba el alcázar islámico en los siglos X y XI. Se trata de la parte inferior de una botella o jarra (le falta el cuello y un asa) de pasta extraordinariamente fina con decoración estampillada de cintas perladas y franjas de roleos entrelazados. En la base tiene un sello en forma de estrella de 8 puntas que contiene también perlas. La exquisitez de su factura relaciona esta pieza con las cerámicas producidas en los siglos IX y X en Siria (en concreto en Raqqa) y en el área mesopotámica, de donde proceden las cerámicas estampilladas sin lustre más antiguas ${ }^{72}$ (figs. 16 y 17).

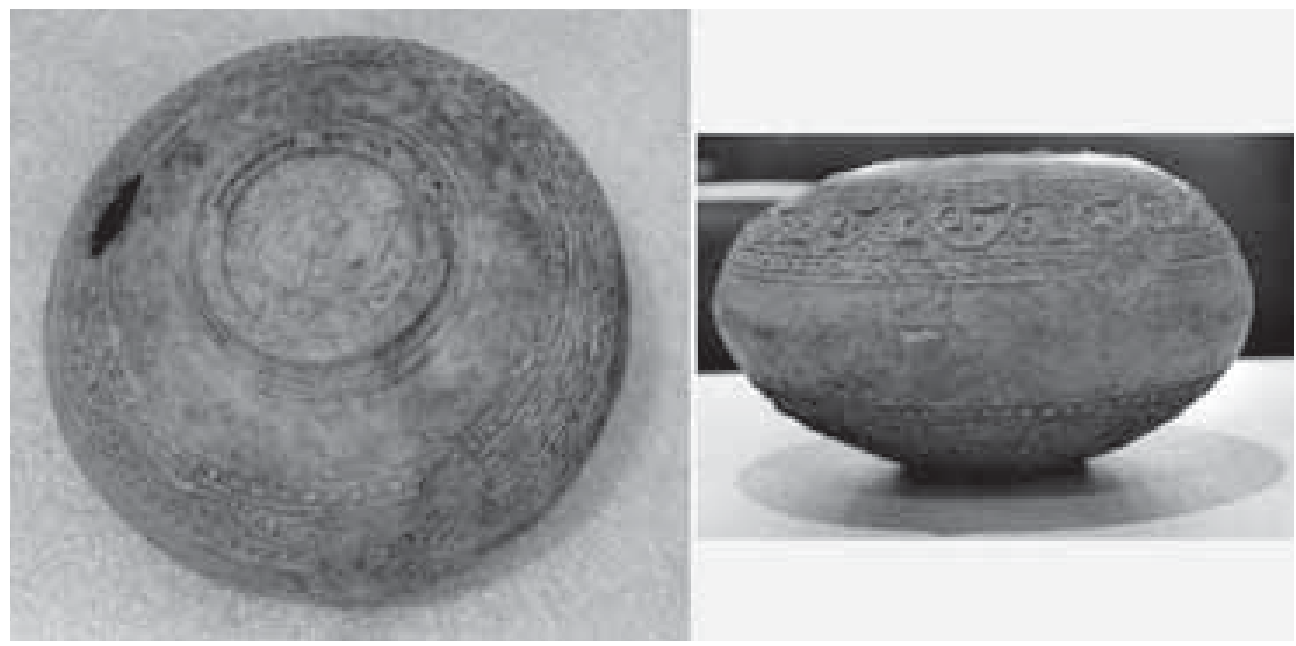

Fig. 16. Vasija de cerámica con decoración estampillada hallada en las excavaciones del convento de Santa Fe de Toledo.

71 R. Azuar, Denia islámica, arqueología y poblamiento, Alicante, 1989 p. 51-55 ("Bronces de la calle Historiador Palau"); Id., "La Taifa de Denia en el comercio mediterráneo del siglo XI", Anales de la Universidad de Alicante, 9 (1992-93), pp. 39-52 (43); sobre los candelabros véase J. ZozAYA, "Ensayo de una tipología y una cronología", Archivo Español de Arte, no 40/158 (1967), pp.133-154; y G. FEHÉRvÁRI, Islamic metalwork of the eighth to fifteenth century in the Keir Collection, Londres, 1976.

72 Fue encontrada en la llamada "Sala del Alfarje", donde se hallaron estructuras del palacio islámico. Se asemeja mucho a los fragmentos de cerámicas procedentes de Raqqa (siglos IX y X), de pasta fina y blanquecina, expuestos en el Museo Nacional de Damasco (véase fig. $n^{\circ}$ 17). En el mismo museo se conserva otro cuenco de origen oriental, muy parecido al que guarda el Museo del Louvre, procedentes respectivamente de Hira, en Iraq, y de Susa, en Irán. Están datados en los siglos VII-VIII y portan sendas inscripciones en cúfico primitivo. H. WEISS (ed.), Ebla to Damascus, Washington, 1985, p. 518 y M. Bernus TaYlor y S. MaKariou, Les arts de l'islam, París, 2001. 


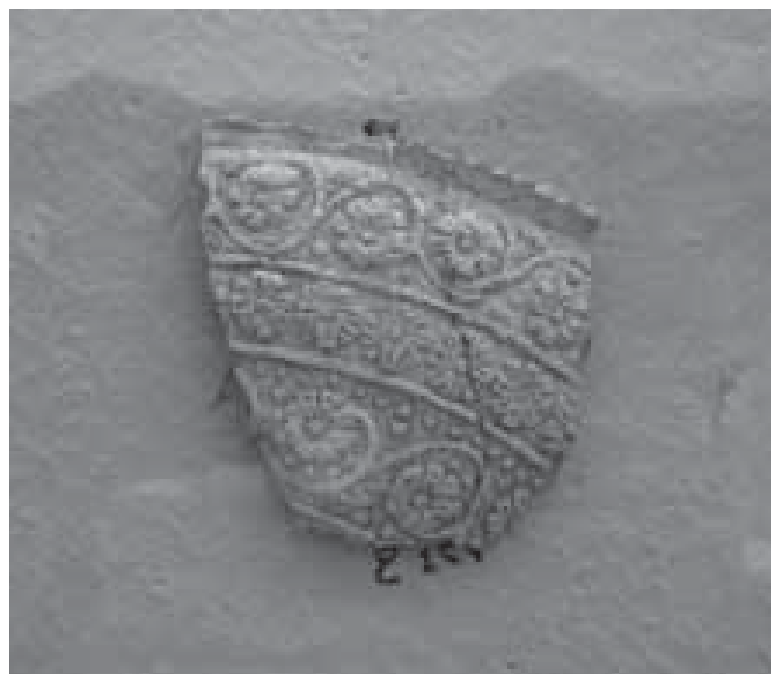

Fig. 17. Fragmento cerámico procedente de Raqqa, siglos IX-X, Museo Nacional de Damasco, Siria.
La llegada de objetos de lujo importados a Toledo justificaría asimismo la posible inspiración en modelos orientales en la decoración de los salones del alcázar en época taifa, momento en que según los textos árabes se hicieron espléndidas construcciones en el mismo ${ }^{73}$. Los yesos policromados y en relieve, con cristales incrustados, que decoran las arquerías halladas son tan refinados que descartan ensayos o tanteos y revelan, por el contrario, una técnica madura; y sin embargo no se conocen por ahora otros ejemplos de esa técnica en al-Andalus. Los contactos del reino de Toledo con el

norte de África, en concreto con Ifriqiyya y con Egipto, ya fueron puestos de relieve por Clara Delgado y Cynthia Robinson, quien ha señalado, asimismo, la presencia de poetas egipcios en el círculo literario cortesano del rey Al-Ma'mun ${ }^{74}$ (fig. 18).

Por último, citaremos la pila de Xátiva, tan conocida como aún enigmática. Según se deduce de la atenta y sugerente lectura en clave antiquizante que hace de ella Milagros Guardia, la pieza recoge una iconografía de origen oriental. Los atlantes de los ángulos, los pugilistas con máscaras y gorros extraños luchando con bastones, la procesión de ofrendas o la mujer que amamanta a un niño (como Isis madre amamantando a Horus, símbolo de la fertilidad) son figuras y escenas paganas que derivan de un contexto muy específico, el Egipto preislámico, o de forma más genérica, del Oriente cristiano ${ }^{75}$. Estas imágenes, previamente cristianizadas, pervivieron y se filtraron en el arte islámico, siendo particularmente visibles en el período fatimí. Los escultores y los talleres de cerámica, tejidos o marfiles de Egipto en los siglos XI y XII se sirvieron de un rico repertorio figurativo que respondía a las necesidades de un variado mercado, con una cliente-

\footnotetext{
73 Sobre la célebre fiesta que da al-Ma'mun a su nieto con motivo de la circuncisión y la descripción del palacio véase C. RoBInson, Palace Architecture..., op. cit., I, pp. 447-466.

${ }^{74}$ C. Delgado señala la similitud de los cipos funerarios, por ejemplo, en "El arte de Ifriqiya y sus relaciones con distintos ámbitos del Mediterráneo: Al-Andalus, Egipto y Sicilia", Al-Qantara,end_of the skype_highlighting 17/2 (1996), pp. 291-320. C. RoBinson, Palace Architecture..., op. cit., I, pp. 430, 443, 458.

75 M. Guardia, «À propos de la cuve de Xàtiva: un exemple de synthèse des substrats classique et islamique», Les Cahiers de Saint-Michel de Cuxa, 35 (2004), pp. 95-113.
} 


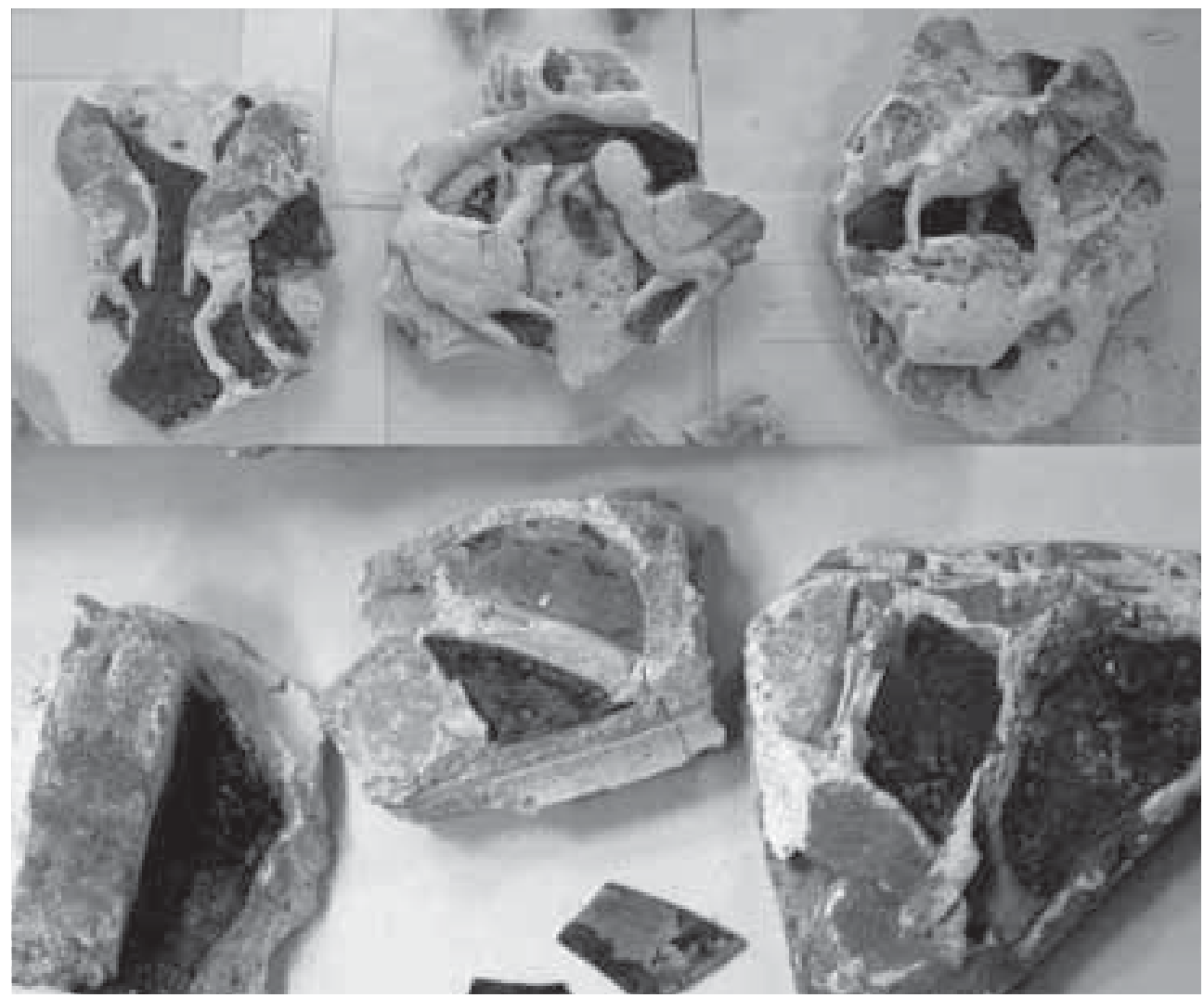

Fig. 18. Toledo. Detalle de los yesos con incrustaciones de vidrio encontrados en las excavaciones del convento de Santa Fe.

la tanto musulmana como cristiana ${ }^{76}$. En opinión de M. Guardia, el significado de estas escenas probablemente no había variado mucho desde la Antigüedad y servían igualmente para la exaltación del buen gobierno del príncipe y la prosperidad de su reino, razón por la que debió escogerse para decorar algún palacio andalusí. Esta interpretación refuerza la idea sugerida por autores como F. Valdés de que esta excepcional pila, carente de información epigráfica que la identifique, pudiera ser una pieza de importación o inspirada en modelos antiguos o antiquisantes, labrada en los siglos XI ó XII ${ }^{77}$.

76 S. Calvo Capilla, "Viajes por el Mediterráneo...”, op. cit., p. 172. Este fenómeno se aprecia muy bien en los motivos presentes en las producciones de cerámica de reflejos dorados.

77 F. Valdés, "Pila de Játiva", Dos milenios en la historia de España: Año 1000, año 2000, Madrid, 2000 , p. 216. 